\title{
Guidelines
}

\section{Canadian Consensus Recommendations on the Management of MET-Altered NSCLC}

\author{
Parneet K. Cheema ${ }^{1,2, *}$, Shantanu O. Banerji ${ }^{3} \mathbb{D}$, Normand Blais ${ }^{4} \mathbb{D}$, Quincy S.-C. Chu ${ }^{5}$, Patrice Desmeules ${ }^{6}$, \\ Rosalyn A. Juergens ${ }^{7}$, Natasha B. Leighl ${ }^{8}$, Brandon S. Sheffield ${ }^{9}$, Paul F. Wheatley-Price 10 \\ and Barbara L. Melosky ${ }^{11}$
}

Citation: Cheema, P.K.; Banerji, S.O.; Blais, N.; Chu, Q.S.-C.; Desmeules, P.; Juergens, R.A.; Leighl, N.B.; Sheffield, B.S.; Wheatley-Price, P.F.; Melosky, B.L. Canadian Consensus Recommendations on the Management of MET-Altered NSCLC. Curr. Oncol. 2021, 28, 4552-4576. https: / / doi.org/10.3390/ curroncol28060386

Received: 22 September 2021 Accepted: 5 November 2021 Published: 9 November 2021

Publisher's Note: MDPI stays neutral with regard to jurisdictional claims in published maps and institutional affiliations.

Copyright: (c) 2021 by the authors. Licensee MDPI, Basel, Switzerland. This article is an open access article distributed under the terms and conditions of the Creative Commons Attribution (CC BY) license (https:/ / creativecommons.org/licenses/by/ $4.0 /)$.

1 Medical Oncology/Hematology, William Osler Health System, Brampton, ON L6R 3J7, Canada

2 Faculty of Medicine, University of Toronto, Toronto, ON M5S 1A8, Canada

3 CancerCare Manitoba Research Institute, Department of Medical Oncology, CancerCare Manitoba, University of Manitoba, Winnipeg, MB R3E 0V9, Canada; sbanerji@cancercare.mb.ca

4 Department of Medicine, Centre Hospitalier de l'Université de Montréal, University of Montreal, Montreal, QC H2X 3E4, Canada; normand.blais.med@ssss.gouv.qc.ca

5 Cross Cancer Institute, Alberta Health Services, Edmonton, AB T6G 1Z2, Canada; quincy.chu@albertahealthservices.ca

6 Service d'Anatomopathologie et de Cytologie, Institut Universitaire de Cardiologie et de Pneumologie de Québec, Université Laval, Quebec City, QC G1V 0A6, Canada; patrice.desmeules@criucpq.ulaval.ca

7 Department of Medical Oncology, Juravinski Cancer Centre, McMaster University, Hamilton, ON L8V 5C2, Canada; juergensr@hhsc.ca

8 Princess Margaret Cancer Centre, University Health Network, Department of Medicine, University of Toronto, Toronto, ON M5S 1A8, Canada; natasha.leighl@uhn.ca

9 Department of Laboratory Medicine, William Osler Health System, Brampton, ON L6R 3J7, Canada; brandon.s.sheffield@gmail.com

10 Department of Medicine, The Ottawa Hospital Research Institute, The Ottawa Hospital, University of Ottawa, Ottawa, ON K1H 8L6, Canada; pwheatleyprice@toh.ca

11 Department of Medical Oncology, BC Cancer-Vancouver Centre, Vancouver, BC V5Z 4E6, Canada; BMelosky@bccancer.bc.ca

* Correspondence: Parneet.Cheema@williamoslerhs.ca

Abstract: In Canada, the therapeutic management of patients with advanced non-small cell lung cancer (NSCLC) with rare actionable mutations differs between provinces, territories, and individual centres based on access to molecular testing and funded treatments. These variations, together with the emergence of several novel mesenchymal-epithelial transition (MET) factor-targeted therapies for the treatment of NSCLC, warrant the development of evidence-based consensus recommendations for the use of these agents. A Canadian expert panel was convened to define key clinical questions, review evidence, discuss practice recommendations and reach consensus on the treatment of advanced MET-altered NSCLC. Questions addressed by the panel include: 1 . How should the patients most likely to benefit from MET-targeted therapies be identified? 2. What are the preferred first-line and subsequent therapies for patients with MET exon 14 skipping mutations? 3 . What are the preferred first-line and subsequent therapies for advanced NSCLC patients with de novo MET amplification? 4. What is the preferred therapy for patients with advanced epidermal growth factor receptor (EGFR)mutated NSCLC with acquired MET amplification progressing on EGFR inhibitors? 5 . What are the potential strategies for overcoming resistance to MET inhibitors? Answers to these questions, along with the consensus recommendations herein, will help streamline the management of $M E T$-altered NSCLC in routine practice, assist clinicians in therapeutic decision-making, and help ensure optimal outcomes for NSCLC patients with MET alterations.

Keywords: non-small cell lung cancer; MET exon 14 skipping mutations; MET amplification; MET inhibitors; EGFR resistance 


\section{Introduction}

Although non-small-cell lung cancer (NSCLC) remains a leading cause of cancer-related death [1], the molecular characterization and classification of its genetic alterations and the subsequent development of targeted therapies has profoundly increased treatment options and overall survival (OS). The mesenchymal-epithelial transition (MET) proto-oncogene encodes the tyrosine kinase receptor for hepatocyte growth factor (HGF). Small molecule inhibitors of $M E T$ are recent additions to the NSCLC-targeted treatment armamentarium.

MET and its ligand, HGF, were characterized in the mid-1980s [2], and the first activating mutations identified within the MET gene were discovered by genome-wide analysis of families with hereditary papillary renal cell carcinoma [3]. Over the past two decades, alterations within and outside the MET kinase domain have been described in several solid tumours, including NSCLC, glioblastoma, breast, renal and colon cancers, as well as cancers of unknown primary origin, suggesting that activated MET plays a significant role in the tumourigenic process in a wide range of cell types [4-11].

$M E T$ is a single-pass transmembrane receptor composed of extracellular, transmembrane, juxtamembrane and tyrosine kinase domains as well as a carboxyterminal docking site [12]. The extracellular portion of MET is a binding site for HGF. Upon HGF binding, MET homodimerization results in the phosphorylation and activation of intracellular domains that stimulate several downstream signalling pathways, including the mitogen-activated protein kinase (MAPK)/extracellular signal-regulated kinase (ERK), phosphatidylinositol 3-kinase (PI3K)/protein kinase B (PKB), mammalian target of rapamycin (mTOR), and Janus kinase (JAK)/signal transducer and activator of transcription (STAT) pathways that promote cell migration, proliferation, and survival [13,14].

The MET gene, located on the long arm of human chromosome 7 (7q21-31), is approximately $125 \mathrm{~kb}$ in length and contains 21 exons [15]. Dysregulation of the MET pathway in lung cancer occurs through gene mutations, amplifications, fusions, rearrangements, and protein overexpression [16].

The most common $M E T$-activating alterations in newly diagnosed non-squamous NSCLC are gene amplification (described in $2 \%$ to $5 \%$ of cases, depending on the different scoring systems adopted in clinical studies) and MET exon 14 (METex14) skipping mutations (occurring in $2 \%$ to $4 \%$ of cases) [17-21]. MET-activating alterations are also reported in $10-20 \%$ of patients with acquired resistance to epidermal growth factor receptor (EGFR) and anaplastic lymphoma kinase (ALK) inhibitors. [22,23] This indicates that MET alterations are sufficient to drive carcinogenesis both as a primary oncogenic driver and as a secondary driver of acquired resistance to targeted therapy [6,24]. Although it has been noted that $M E T$ overexpression can be detected by immunohistochemistry (IHC) in as many as $20-25 \%$ of patients [17], the correlation between MET IHC and MET genomic alterations is poor $[25,26]$.

Several clinical trials have reported positive outcomes with $M E T$ inhibitors in three clinically relevant $M E T$ alterations:

1. METex14 skipping mutations

2. De novo $M E T$ amplification

3. MET amplification in acquired resistance to EGFR inhibitors

The trial results impact the management of NSCLC patients presenting with these three MET alterations and have created a need for consensus recommendations that can streamline and integrate diagnostic approaches to identify patients that can benefit from novel therapies. Moreover, due to the availability of other therapeutic options for these patients, including immune checkpoint inhibitors (ICIs), there is an added need for expert guidance on therapeutic approaches with optimal short- and long-term outcomes. Lastly, the therapeutic management of patients with advanced NSCLC and rare actionable mutations likely differs across Canada due to variations in access to molecular testing and drug funding, further highlighting the need for such recommendations. 


\section{METex14 Skipping Mutations}

Epidemiology, Clinical Features, and Prognostic Implications

METex14 skipping mutations are detected in 2-4\% of lung adenocarcinoma cases [22-24], a prevalence comparable to $A L K$-rearranged lung cancer [27]. These mutations usually occur in older patients (median age of 72 years) with a higher percentage of eversmokers compared to patients with tumours harbouring other oncogenic alterations such as EGFR/ALK/ROS1 [21]. METex14 skipping mutations are usually mutually exclusive with other lung cancer-driving mutations, suggesting it is an independent oncogenic driver $[19,20]$. In a study of 933 patients with nonsquamous NSCLC, no patients with $M E T$ ex14 skipping mutations had activating mutations in KRAS, EGFR or ERBB2, or rearrangements involving $A L K, R O S 1$ or RET [20]. However, in another study that included 298 patients with METex14 skipping mutations, KRAS mutation was reported in 3\% [21]. Co-occurring genomic alterations also include mutations in TP53, loss of CDKN2A/B, and amplification of $M E T, M D M 2$, and $C D K 4 / 6$ [21-23]. Furthermore, although a substantial proportion of METex14 lung cancers express PD-L1, the median tumour mutational burden (TMB) is lower compared with unselected NSCLCs [28].

A high frequency of METex14 skipping mutations has initially been reported in the NSCLC non- squamous subtype of pulmonary sarcomatoid carcinoma (PSC) [29], ranging from $5-32 \%$ of patients $[30,31]$. Most recently, the incidence of METex14 skipping mutations in patients with PSC was shown to be 7-8\% [32,33]. METex14 skipping mutations have also been found in a very small percentage of patients with squamous cell carcinoma (SCC). Lam VK et al. reported METex14 alterations in 4 out of 385 (1\%) SCC patients [34]. In two recent clinical trials that assessed the efficacy of $M E T$ inhibitors in patients with $M E T$ ex14 skipping mutations, GEOMETRY mono-1 [35] and VISION [36], patients with squamous and non-squamous histology were included. Squamous patients represented a significantly smaller proportion (8/97 patients in GEOMETRY-mono-1 and 7/99 patients in VISION with METex14 skipping mutations had SCC histology).

METex14 NSCLC is generally associated with aggressive disease, resistance to anticancer therapies, and poor prognosis when not treated with MET inhibitors [37-40]. Earlier studies indicate that the overall response rate (ORR) to ICIs in NSCLC patients with METex14 skipping mutations is low (approximately 16\%), with a median PFS of approximately $2-5$ months $[28,41]$. For first-line chemotherapy, a recent study revealed a median OS of about 9.5 months and a PFS of 4.0 months [42]

In a retrospective analysis of radiological features of NSCLC patients harbouring METex14 skipping mutations, the primary tumour seemed to present as solid and peripheral masses with a high frequency of multifocal and extrathoracic metastases, mainly to the bone, brain, and adrenal glands [43].

\section{De novo MET Amplification}

\section{Epidemiology, Clinical Features, and Prognostic Implications}

$M E T$ amplification is thought to dysregulate $M E T$ pathway signalling via protein overexpression and constitutive kinase activation. De novo $M E T$ amplification occurs in approximately $1-5 \%$ (depending on the different scoring systems adopted in clinical studies) of NSCLC cases $[6,44-46]$ and has been associated with poor survival in patients with surgically resected early-stage disease [26,44,47].

While METex14 skipping mutations are most commonly reported with adenocarcinomas given the overall incidence of this histology, MET amplification is more frequently identified in squamous cell carcinomas (SCC) [48]. Former or current smokers represent over $50 \%$ of patients with $M E T$ amplification in tumours, and a history of ever smoking is more common in SCC than in adenocarcinoma $(71 \%$ vs. $34.3 \% ; p<0.001)$ [48]. The magnitude of MET amplification measured by MET gene copy number (GCN) status ( $\geq 5$ copies / cell) does not appear to be associated with gender, smoking history, histology, or stage. Multivariable analysis showed that a higher MET GCN is significantly associated with shorter survival in SCC [48]. 
Patients presenting with MET amplification tend to be younger (average age of 66 years), male, and smokers. MET amplification occurs more frequently as a subclonal event, often co-occurring with other pathogenic mutations (including NRAS, KRAS and TP53), and is usually a late genetic event [16,49]. Co-occurrence of MET amplification in METex14 lung cancer is found in approximately $15-20 \%$ of cases, indicating that MET dependency in lung cancer can be driven by synergistic genomic events [21,38]. MET amplification is often present in other tumour types, including $6 \%$ of gastroesophageal carcinomas [50]. In both lung and gastric cancers, MET amplification is associated with higher histologic grade, advanced disease, and unfavourable prognosis [51].

\section{MET Amplification as Acquired Resistance to EGFR Inhibitors Epidemiology, Clinical Features, and Prognostic Implications}

MET amplification is a potential resistance pattern to EGFR inhibition in NSCLC, accounting for $5-22 \%$ of acquired resistance to first- and second-generation EGFR inhibitors [52-54]. In the phase III AURA3 trial, analysis of plasma samples from 73 EGFR T790M-positive patients with acquired resistance to the third-generation EGFR tyrosine kinase inhibitor (TKI) osimertinib showed that MET amplification is the most common resistance mechanism (19\%), followed by EGFR C797S mutation (7\%) [55]. Similar observations have been made in studies with rociletinib, another third-generation EGFR TKI that is no longer in development $[56,57]$. In the phase III FLAURA trial, next generation sequencing (NGS) analysis of 91 plasma samples from patients progressing on first-line osimertinib reported MET amplification in 15\% of samples [58]. MET amplification is also detected in other oncogene-addicted NSCLCs including those with ALK rearrangements, in which $15 \%$ of tumour biopsies from patients relapsing on next-generation ALK inhibitors detected MET amplification [23].

The mechanism by which MET amplification causes resistance to EGFR inhibitors is associated with EGFR-independent phosphorylation of ErbB3 and downstream activation of the PI3K/AKT pathway, bypassing EGFR inhibition [59]. Patients with MET amplification following osimertinib resistance tended to have inferior survival compared to patients without an increase in MET amplification (median PFS of 3.5 vs. 9.9 months; median OS of 15.6 months vs. 30.7 months) [60].

MET amplification after EGFR TKI may heterogeneously distribute the amount of metastatic sites; therefore, liquid biopsy may aid in detecting the alteration. A recent study showed that liquid biopsy could provide important insights into the heterogeneity of TKI resistance mechanisms in NSCLC [61].

\section{Identifying Patients Most Likely to Benefit from MET-Targeted Therapies}

\subsection{Pre-Analytical Considerations}

\subsubsection{Testing Strategies}

Dysregulated MET expression and activity can be detected at the DNA, RNA, and protein levels. Assays commonly used in clinical trials include IHC to detect protein overexpression, fluorescence in situ hybridization (FISH) to identify gene amplification, reverse transcription polymerase chain reaction (RT-PCR) to detect gene mutations, and next-generation sequencing (NGS) to detect both amplifications and mutations, depending on the sample used (i.e., DNA and/or RNA).

Several studies demonstrate a poor correlation between IHC and METex14 skipping mutations and MET amplification, with negative predictive values of $95 \%$ for $M E T$ amplification and $94 \%$ for METex14 skipping mutations [25,26]. An analysis of the French IFCT-PREDICT.amm cohort, which consisted of 843 patients with treatment-naive advanced NSCLC, revealed similar rates of METex14 skipping mutations in patients with no or low vs. high MET expression by IHC [62]. Combined mutation and GCN analysis in patients with high MET protein-expressing tumours demonstrate that only $10 \%$ of these patients had METex14 skipping mutations or MET gene amplification. The majority of cases with high $M E T$ expression (MET $3+$ immunoscore, i.e., $\geq 50 \%$ of tumour cells showing 
high-intensity staining) do not appear to be associated with alterations of the MET gene. Consequently, these findings do not support the use of MET IHC as a surrogate marker or screening for genomic MET alterations.

Laboratories aiming to implement clinical MET testing must select a methodology or testing algorithm that integrates all other standard-of-care lung cancer biomarkers reported within the recommended turnaround time. The methodology should take into consideration all other factors associated with the addition of the assays to the existing workflow (ease of use, technical hands-on time, and interpretation). The performance characteristics of the assays should be thoroughly validated with characterized samples representative of clinical practice, including small specimens. Other key considerations include the integration of complementary assays in order to respond to issues related to small specimens and assay failure/insufficiency rates, as well as cost-effectiveness.

Considering that patients with currently approved clinically actionable alterations (i.e., EGFR, ALK, ROS1, RET and BRAF) account for 15-20\% of non-squamous NSCLC and rapid emergence of additional targets (e.g., MET alterations, KRAS G12C), a shift towards diagnostic platforms that allow multigene panel testing (e.g., NGS technology) is the most appropriate approach, as opposed to sequential single-gene testing such as FISH or RT-PCR. In this context, even if the relative number of patients with a specific molecular alteration represents only a small percentage of the whole NSCLC population, testing for new actionable drivers would have a minimal additional impact on service delivery. If sufficient numbers of mutations are included, upfront NGS represents a feasible, cost-effective method of diagnostic molecular profiling compared with sequential testing strategies [63]. Furthermore, having in-depth knowledge of the mutation status of patients is critical as patients with some oncogenic drivers might have an inferior clinical benefit from alternative therapies such as ICIs. Patient identification is essential for choosing an individualized therapeutic strategy [64].

Multiplex gene testing is supported worldwide by several international pathology and oncology association guidelines [65-67]. In addition, the majority of European countries have adopted this approach and developed country-specific recommendations [68].

Testing for METex14 skipping mutations should be performed for all treatment-eligible patients with advanced non-squamous NSCLC, irrespective of clinical characteristics such as patients with PSC, due to the higher frequency of METex14 skipping mutations found in these tumours. Ideally, reflex testing should be initiated routinely by the pathologist at the diagnosis stage in patients with advanced-stage non-squamous NSCLC. The advantages of reflex testing include optimal tissue management and reduced waiting time for results [69-71]. In patients with SCC, testing should be performed at a minimum in non-smokers with advanced disease that are treatment-eligible, on-demand by a clinician. Based on access to local testing, all patients with advanced SCC irrespective of smoking status could be tested, given the presence of $M E T$ alterations in this patient population. This would improve biomarker testing in this group and increase the number of patients with SCC that would be able to access targeted therapy if appropriate.

\subsubsection{Tissue versus Liquid Biopsy}

Histology is currently the gold standard for molecular analysis in NSCLC. However, as a large proportion of NSCLC patients present with advanced disease and associated health-related risks, tissue samples for molecular testing are predominantly small biopsies and cytological samples. In certain situations (e.g., tissue biopsy with scarce tumour cells; time for tissue biopsy is too lengthy; invasive procedures are contraindicated), liquid biopsy could be considered where available.

Numerous studies have demonstrated a relatively good correlation between liquid and tissue biopsy results and the potential of liquid biopsy with cell-free DNA, including circulating tumour DNA (ctDNA), to detect actionable genomic alterations including MET alterations [72,73]. Thus, driver mutations found by liquid biopsy should be considered actionable. 
Circulating tumour DNA, a subset of total cell-free DNA, is released through lysis of apoptotic and necrotic cells, digestion of tumour cells by macrophages, or by direct secretion of DNA by tumour cells [74]. The fraction of ctDNA varies depending on tumour stage, disease burden, vascularization, and biological features (i.e., apoptotic rate, metastatic potential of the cancer cells) $[75,76]$. The half-life of ctDNA in the bloodstream varies between 16-150 min, making ctDNA a "real-time" biomarker that reflects tumour burden [74].

When selecting a liquid NGS assay, one should consider the coverage of MET introns, the ability to detect copy number alterations, and the differences between approaches using ctDNA and those using both ctDNA and ctRNA (see analytical considerations for more detail). On top of this, the overall limitations of plasma-based NGS, including sensitivity as it relates to the stage and burden of disease, should be considered.

\subsubsection{Turnaround Time and Reporting of Biomarker Test Results}

Rapid turnaround time for biomarker test results, especially in newly diagnosed NSCLC requiring therapy, is extremely important for timely treatment initiation. The College of American Pathologists recommends a maximum 10-day turnaround time from sample receipt in the laboratory to report generation [65]. It is also recommended that the pre-laboratory turnaround time does not exceed three business days and that the post-laboratory turnaround time is less than $24 \mathrm{~h}$ [77]. However, the maximum acceptable time to wait for biomarker results for each patient should be at the clinician's discretion and balanced between missed treatment opportunities and the benefits of waiting for appropriate targeted therapy. The biomarker test results should be compiled and ideally reported in a single comprehensive report by the pathologist, including PDL1 status. This is the optimal process to guide treatment decisions, as PDL1 status alone for patients with non-squamous histology is insufficient to guide treatment decisions.

\subsubsection{Recommendations}

1. Testing for METex14 should be performed as part of a comprehensive panel that includes current standard-of-care biomarkers as summarized by international guidelines. All advanced stage non-squamous NSCLC patients, including patients with PSC and those without alterations in EGFR, ALK or ROS1 should be tested, regardless of clinicopathologic characteristics.

2. Reflex biomarker testing for METex14 skipping mutations should be initiated by the pathologist at the time of initial diagnosis in all patients diagnosed with advancedstage non-squamous NSCLC.

3. METex14 testing in advanced SCC should be performed upon the oncologist's request in treatment-eligible non-smokers.

4. Considering the availability of multigene panels, there is increasing consensus that smokers with advanced SCC that are treatment-eligible should also be considered for testing given the presence of $M E T$ alterations in this population.

5. Liquid biopsy should be considered if a tissue biopsy is unavailable, inadequate for molecular testing, when invasive procedures for tissue procurement are contraindicated, or when urgent treatment decisions are required and delays are expected with tissue testing.

6. Negative results by liquid biopsy do not mean the absence of the target; if possible, reflex to tissue testing is recommended.

7. Regardless of the type of biopsy (tissue or liquid), identified actionable genomic alterations, including METex14, are acceptable as valid indications for approved MET targeted treatments.

8. The maximum acceptable turnaround time (from the acquisition of tissue to the oncologist having the report) for all biomarkers should not exceed 21 calendar days. In certain situations, accelerated testing should be available. 
9. Biomarker test results should be compiled and ideally reported in a single comprehensive biomarker report by the pathologist, including PD-L1 expression.

\subsection{Analytical Considerations}

\subsubsection{Detection of METex14 Skipping Mutations}

METex14 skipping mutations are a heterogeneous group of indels and missense mutations that result in post-translational modifications detectable at the RNA level, which poses challenges and requires specific analytical and diagnostic considerations [78]. Genomic characterization of METex14 samples has shown that DNA changes display remarkably diverse sequences, with variants extending deep into intronic non-coding regions adjacent to exon 14 [19]. Genomic variants altering or ablating a splicing site must be detected when using a DNA-based approach, while RNA sequencing allows characterization of altered splicing and fusion of exon 13 to 15 regardless of underlying genomic alteration. For clinical use in NSCLC where comprehensive biomarker testing is warranted, the main types of strategies offered by commercial assays include amplicon-based and hybrid-capture-based NGS. Several studies have explored their performance in comparison to conventional molecular assays (i.e., RT-PCR, Sanger sequencing) [78-80].

The main limitation of small DNA-based amplicon panels is improper coverage. Comparison of such panels with RNA-based anchored-multiplex (AMP)-PCR revealed a higher incidence of identified alterations in NSCLC samples tested by the RNA-based assay (4.2\% versus $1.3 \%$ ), with 6 of 10 AMP-PCR-positive results negative on the DNA-based assay [80]. This is in line with an in silico study which reported that commercially available DNA-based NGS panels could only detect $63 \%$ of literature-described splicing mutations associated with METex14 [81]. However, performance was improved after the customization of panels with additional MET amplicons [82]. Nonetheless, the interpretation of an $M E T$ ex14 variant without confirmatory splicing alteration with RNA sequencing can be problematic in some circumstances.

The role of complementary RNA sequencing for proper identification of METex14 also applies for hybrid-capture panels. This was shown in 252 driver negative NSCLC samples, based on a large DNA-based NGS panel that underwent AMP-PCR RNA sequencing [83]. Six (2.5\%) METex14-positive cases were revealed amongst other oncogenic fusions, of which five cases had intronic variants located as far as $40 \mathrm{bp}$ away from the intron 13 splice site on manual review of the DNA sequencing data [83]. Considerations involved in such false-negative cases, outside of assay design with improper genomic coverage of regions involved in splicing (large intronic regions as well as branch site, polypyrimidine tract, splice acceptor and donor site of $M E T$ exon 14), include large genomic deletions to primer binding sequences as well as bioinformatics filtering $[80,83]$. On the other hand, RNA-based assays are highly dependent on RNA quality [80]. All of these considerations, which affect FFPE- and plasma-based NGS, highlight the need for properly validated assays and complementary techniques in some clinical contexts (e.g., driver negative case) in order to achieve optimal METex14 detection.

\subsubsection{Recommendations}

10. METex14 testing methodology should undergo specific validation of performance characteristics before clinical implementation, whether it is based on a hybrid-captureor amplicon-based NGS strategy on DNA or in combination with or complemented by RNA-based NGS.

11. Due to a high risk of poor sensitivity, caution is needed when amplicon-based DNA panels are used to capture some genomic METex14 skipping mutations without combined RNA sequencing.

12. Clinicians and pathologists should be aware of and consider assay limitations when interpreting results, including whether a particular assay includes intronic regions of $M E T$ and whether it is capable of identifying skipping alterations. 
13. Although the panel does not recommend single-gene testing for METex14 skipping mutations, additional multi-target testing is recommended for patients who are driverunknown following single-gene testing. The selection of a proper molecular method should follow the same considerations as for NGS in terms of performance.

14. MET IHC is not recommended as a screening tool for METex14 skipping mutations, as the data indicate a poor correlation between MET IHC and METex14 skipping mutations.

\subsubsection{MET Amplification}

MET amplification is thought to dysregulate $M E T$ pathway signalling via protein overexpression and constitutive kinase activation; however, it is unclear whether MET amplification levels change over time and/or after some therapies. MET GCN is a continuous variable, and the definition of a positive threshold affects incidence, rate of overlap with other genotypes, and ability to predict the efficacy of MET inhibitors [84].

The most frequent technologies used to assess MET GCN variations in the clinical setting are FISH and NGS. While FISH is conventionally used to assess amplification, NGS is becoming routine in molecular diagnostics and provides a means to assess MET amplification in the context of comprehensive genomic profiling.

Although MET inhibitor response rate is largely driven by copy number, a consensus on the definition of MET positivity based on GCN has yet to be reached. With FISH, two different quantification criteria are used: either an increase in absolute copy number (e.g., mean copy number of the gene per cell), or an increase in the ratio of gene copies relative to other areas on the same chromosome (typically the centromere of the chromosome where the gene is located, that is, the ratio of $M E T$ to chromosome 7 centromere, MET/CEP7) [84].

Recent clinical trials with $M E T$ inhibitors define different cut-offs for $M E T$ amplification positivity. The PROFILE 1001 with crizotinib used MET/CEP7 ratios and defined cut-offs of $\geq 1.8$ to $\leq 2.2$ as low, $>2.2$ to $<4$ as medium, and $\geq 4$ as high MET amplification [85]. The cut-offs assessed in the GEOMETRY-mono 1 trial with capmatinib were GCNs of $<4,4$ to 5, 6-9 and $>10$ [35]. Finally, the most recent analysis from the VISION trial with tepotinib, which utilized liquid biopsy, defined MET amplification positivity as MET GCN > 2.5 [86].

\subsubsection{Recommendations}

15. When selecting an NGS panel for use in NSCLC, pathologists are encouraged to utilize an assay that provides copy number status, and to ensure that copy number coverage of $M E T$ is included.

16. When reporting the MET copy number status or copy number ratio, it is important that pathologists and end-users are aware of the particular cutpoints being used. While no definitive cutpoints have been established, practitioners are encouraged to monitor the emerging data on this topic.

17. Users should be aware of any limitations to copy number assessment by NGS, such as low uniformity and low tumour content.

18. In select scenarios, single-gene tests for MET amplification, such as FISH, can be utilized. This could include patients with resistance to EGFR TKI therapy.

19. MET IHC is not recommended as a screening tool for MET amplification, as the data indicate a poor correlation between MET IHC and MET amplification.

20. Liquid biopsy may be considered, particularly when testing for MET amplification as a resistance mechanism, while recognizing the lower sensitivity of plasma-based assays compared to tumour tissue testing. The limitations of liquid NGS in general, as well as the particular assay, should be considered. However, MET amplification detected by plasma-based assays should be considered actionable. 


\section{What Are the Preferred First-Line and Subsequent Therapies for Patients with Advanced NSCLC Harbouring METex14 Skipping Mutations?}

- What is the preferred first-line therapy for treatment-naïve patients with METex14 skipping mutations?

- What are the preferred subsequent lines of therapy for patients with METex14 skipping mutations unexposed to MET inhibitors?

\subsection{ICIs in Patients with METex14 Skipping Mutations}

The results of the KEYNOTE 024 [87], KEYNOTE 189 [88] and KEYNOTE 407 [89] trials demonstrate favourable long-term outcome effects with ICI monotherapy in patients with a tumour proportion score for programmed death-ligand 1 (PD-L1) of $\geq 50 \%$, as well as with an ICI in combination with chemotherapy. In the Checkmate 227 trial, firstline nivolumab plus ipilimumab improved OS compared to chemotherapy in patients with NSCLC, independent of PD-L1 expression level [90]. Next, the Checkmate 9LA trial confirmed that nivolumab plus ipilimumab with two cycles of chemotherapy provided a significant improvement in OS versus chemotherapy alone [91]. All of these trials excluded patients with EGFR or ALK mutations, but not those with METex14 skipping mutations. However, the number of patients included with these alterations in these studies has not been reported. Based on these trials, recent recommendations from the American Society of Clinical Oncology (ASCO) and Ontario Health (OH; Cancer Care Ontario) consider ICI \pm chemotherapy as the standard of care for treatment-naïve EGFR and ALK-negative stage IV NSCLC [92].

A large international retrospective study (IMMUNOTARGET) assessed the benefits of ICIs in 551 patients with advanced NSCLC and oncogenic driver alterations [41]. The study included 36 patients with MET alterations (76.5\% former or current smokers; 23 with METex14, and 13 with MET amplification). There was a trend toward longer median PFS with an ICI in patients with METex14 alterations (4.7 months) compared to those with MET amplification (1.3 months, $p=0.09$ ). Median PFS did not correlate with smoking status. Median OS was 25 months in patients with METex14 skipping mutations and 8.0 months in those with MET amplification. The objective response rate (ORR) in the entire MET cohort was $16 \%$.

Similar responses were achieved by Sabari et al. [28]. Among 111 evaluable tumour samples from NSCLC patients with METex14 skipping mutations, a PD-L1 expression of $0 \%, 1-49 \%$, and $\geq 50 \%$ was seen in $37 \%, 22 \%$, and $41 \%$ of samples, respectively. The median tumour mutational burden (TMB) of tumours harbouring METex14 skipping mutations was lower than that of unselected NSCLCs, and there was no association between PD-L1 expression and TMB. Of the 111 cases, only 24 were response-evaluable, in whom the ORR was $17 \%$ and the median progression-free survival (PFS) was 1.9 months. Response was not enriched in tumours with PD-L1 expression $\geq 50 \%$ or high TMB. The authors concluded that occasional response to PD-1 blockade could be achieved; however, overall clinical efficacy was modest. In contrast to these data, some recently published small case series have reported response in about $50 \%$ of cases and PFS of over two years in patients treated with ICIs [93-95].

A report on over 1300 NSCLC patients with METex14 skipping mutations confirmed that TMB is significantly lower in these patients compared to METex14 wildtype NSCLC (3.6 vs. 7.0 mut/Mb) [96]. METex14 NSCLC was also enriched for high ( $\geq 50 \%)$ PD-L1 positivity compared to wildtype NSCLC (48\% vs. 29\%). The report, however, did not include other relevant patient characteristics (i.e., smoking status), and the authors concluded that additional data are needed to determine the predictive role of these biomarkers for ICI response in patients with NSCLC harbouring METex14 skipping mutations. Several studies reported that PD-L1 expression in METex14 tumours could be relatively high ( $\geq 50 \%$ expression in $40-70 \%$ ) $[28,96,97]$. This raises questions about the relevance of PD-L1 expression as a biomarker for patients with advanced METex14 NSCLC, as well as the safety and efficacy of ICIs in this population; notably the balance between potential ef- 
ficacy and toxicity associated with receiving TKIs, in particular crizotinib, following ICI therapy $[95,98]$. According to Canadian real-world data presented at ASCO 2021, six out of seven patients receiving crizotinib post-ICIs experienced an early grade $\geq 3 \mathrm{AE}$ (four transaminitis, two pneumonitis) resulting in permanent discontinuation of TKI in half of the patients [95]. Biomarkers and characteristics that could indicate which patients will have ICI-related events are unknown.

Based on clinical trial data and current practice, it is apparent that the optimal sequence of therapy in patients with METex14 NSCLC is yet to be determined. Several factors are involved in therapeutic decision-making, including the severity of disease, smoking status (which could impact TMB), likelihood of response to ICIs, and the likelihood of rapid deterioration. Based on the limited evidence, there are some concerns that, similar to activity in other driver mutations (EGFR and ALK), monotherapy ICIs may not have robust activity in patients with METex14 skipping mutations. However, unlike patients with $E G F R$ and $A L K$, where a majority of patients are non-smokers, $50 \%$ of patients with METex14 alterations present with a history of smoking. Patients with PSC tend to be very heavy smokers, and often respond well to ICIs, especially if there is high PD-L1 expression [99,100], whereas non-smokers have less benefit from ICIs [101]. Thus, the panel recognized that smoking status may be implicated in decision-making and optimal sequencing of therapy in NSCLC patients with METex14 skipping mutations.

\subsection{MET Inhibitors in Patients with Advanced METex14 Skipping Mutations}

Multiple MET inhibitors, including both small molecule TKIs and monoclonal antibodies against MET or HGF have been in clinical development since the early 2000s [102]. MET TKIs can be divided into type I and type II, based on their binding site (Table 1) [103], and both types are ATP-competitive. Type I binds to MET's unique autoinhibitory conformation by interacting with Y1230 in the MET activation loop, while type II binds to the adenosine binding site and extends to the hydrophobic back pocket.

Table 1. TKIs Targeting METex14 skipping mutations.

\begin{tabular}{|c|c|c|c|c|c|}
\hline Compound & Targets & $\begin{array}{l}\text { Type of } \\
\text { Inhibitor }\end{array}$ & $\begin{array}{l}\text { Enzyme } \\
\mathrm{IC}^{50}, \mathrm{nM}\end{array}$ & $\begin{array}{l}\text { Cellular IC }^{50} \\
\text { (Cell Line), nM }\end{array}$ & $\begin{array}{l}\text { Clinicaltrials.gov } \\
\text { NCT Number }\end{array}$ \\
\hline Crizotinib & $M E T, A L K$, ROS1 & Type Ia & $<1.0$ & 8 (A549) & $\begin{array}{c}\text { NCT00585195 (PROFILE-1001) } \\
\text { NCT02465060 (NCI-MATCH) } \\
\text { NCT02499614 (METROS) } \\
\text { NCT02664935 (Matrix) }\end{array}$ \\
\hline Capmatinib & MET & Type Ib & 0.13 & $\begin{array}{l}0.4(\mathrm{H} 596) \\
0.7(\mathrm{~A} 549)\end{array}$ & $\begin{array}{l}\text { NCT02750215 } \\
\text { NCT01324479 }\end{array}$ \\
\hline Tepotinib & MET & Type Ib & 3 & 9 (EBC-1) & NCT02864992 (VISION) \\
\hline Savolitinib & MET & Type Ib & 5 & 4 (H1993) & NCT02897479 \\
\hline Bozitinib & MET & Type I & 8 & $\begin{array}{c}5.8 \text { (LU1901) } \\
17 \text { (LI0612) }\end{array}$ & $\begin{array}{l}\text { NCT03175224 } \\
\text { NCT01639508 }\end{array}$ \\
\hline Cabozantinib & $\begin{array}{l}\text { MET, VEGFR2, } \\
\text { RET, KIT, TIE-2, } \\
\text { AXL }\end{array}$ & Type II & 1.3 & 7.8 (PC3) & NCT02544633 \\
\hline Glesatinib & $\begin{array}{l}\text { MET, VEGFR, } \\
\text { RON, TIE-2 }\end{array}$ & Type II & 1 & 20 (MKN45) & NCT02920996 \\
\hline Merestinib & $\begin{array}{l}\text { MET, TIE-1, AXL, } \\
\text { ROS1, DDR1/2, } \\
\text { FLT3, MERTK, } \\
\text { RON , MKNK1/2 }\end{array}$ & Type II & 4.7 & $\begin{array}{l}35(\mathrm{H} 460) \\
52(\mathrm{~S} 114)\end{array}$ & NCT02897479 \\
\hline
\end{tabular}

$A L K$, anaplastic lymphoma kinase; DDR1/2, discoidin domain receptor tyrosine kinase $1 / 2$; FLT3, FMS-like tyrosine kinase 3; IC 50 , half inhibitory concentration; MERTK, MER receptor tyrosine kinase; $M E T$, mesenchymal-epithelial transition; $M K N K 1 / 2$, mitogen-activated protein (MAP) kinase-interacting serine/threonine-protein kinase 1/2; NCT, national clinical trial; TKIs, tyrosine kinase inhibitors. 
Type I inhibitors can be further divided into type Ia (crizotinib) and type Ib (Table 1). Type Ib inhibitors are highly specific for MET and have fewer off-target effects compared to type Ia.

\subsubsection{Crizotinib}

Crizotinib is a multikinase inhibitor with strong activity against $A L K$, ROS1 and MET alterations. The antitumour activity and safety of crizotinib (250 $\mathrm{mg}$ twice daily) was assessed in the PROFILE-1001 trial, which included 69 patients with advanced NSCLCs harbouring METex14 skipping mutations [85]. ORR was $32 \%$ among 65 response-evaluable patients and there was no difference in ORR by type of MET alteration, either by splice-site region (32\% for splice donor site, $31 \%$ for splice acceptor site) or by mutation type (36\% for base substitution, $25 \%$ for indel). The median DOR was 9.1 months. Median PFS was 7.3 months and $54 \%$ of participants were progression-free at 6 months. Median OS was estimated at 20.5 months, with 6- and 12-month rates of $87 \%$ and $70 \%$, respectively. Elevated transaminase levels and dyspnea were the most frequent grade 3 treatment-related adverse events (TRAEs), with each observed in $4 \%$ of participants. There was one case each of grade 4 hypophosphatemia, lymphopenia, pulmonary embolism, and one fatal case of treatment-related interstitial lung disease.

The antitumour activity of crizotinib was also confirmed in a phase II prospective multicentre two-arm trial in patients with NSCLC with ROS1 rearrangements (cohort A; $n=26$ ) or MET deregulation (cohort B; $n=26$ ) [104]. Cohort B included nine patients with METex14 skipping mutations, sixteen with MET amplification (threshold MET/CEP7 > 2.2), and one with both amplifications and METex14 skipping mutations. In the entire MET cohort, eleven patients $(42 \%)$ had stable disease (SD), for an overall disease control rate (DCR) of $69 \%$. With a median follow-up of 21 months, median PFS, median OS and DOR were 4.4 months, 5.4 months, and 3.7 months, respectively. Out of nine patients with METex14 skipping mutations, only one had a partial response, although five had SD (DCR 67\%).

These trials indicate that although crizotinib has some activity in patients with $M E T$ alterations, the ORR with crizotinib in these patients is lower compared to that achieved with targeted therapy for many other NSCLC driver mutations. Although crizotinib was the first MET TKI to be evaluated in this patient group, more promising data have been reported with more selective agents.

\subsubsection{Tepotinib}

The phase II VISION trial assessed the efficacy of tepotinib (500 mg once daily), a type $1 \mathrm{~b} M E T$ inhibitor, in patients with METex14 skipping mutations (cohort A) [36]. In treatment-naïve patients $(n=65)$, ORR was $44.6 \%$, median DOR was 10.8 months (Table 2$)$, and PFS was 8.5 months. In previously-treated patients $(n=81)$, ORR was $45.7 \%$, median DOR was 11.1 months, and median PFS was 10.9 months. Tepotinib was generally well tolerated across therapy lines, with mostly mild to moderate AEs and few discontinuations. The most common TRAE, peripheral edema (63\% all grades; grade $\geq 3,7.5 \%$ ), rarely led to discontinuation (4\%). Other common AEs included nausea (26\%), diarrhea (22\%), creatinine increase $(18 \%)$, and hypoalbuminemia $(16 \%)$.

Based on this data, Health Canada has issued a marketing authorization for tepotinib with conditions, pending the results of trials to verify its clinical benefit. In Canada, tepotinib is indicated for the treatment of adult patients with locally advanced unresectable or metastatic NSCLC harbouring METex14 skipping alterations. 
Table 2. Efficacy of Type Ib MET inhibitors in metastatic NSCLC with METex14 skipping mutations.

\begin{tabular}{|c|c|c|c|c|c|}
\hline Drug & Cohort & $\begin{array}{r}\text { ORR, \% } \\
(95 \% \mathrm{CI})\end{array}$ & $\begin{array}{c}\text { mDOR, Months } \\
(95 \% \text { CI })\end{array}$ & $\begin{array}{l}\text { mPFS, Months } \\
\text { (95\% CI) }\end{array}$ & $\begin{array}{c}\text { mOS, Months } \\
\quad(95 \% \text { CI })\end{array}$ \\
\hline \multirow{4}{*}{ Tepotinib } & Overall $(n=146)$ & $45.2(37.0,53.6)$ & $11.1(8.4,18.5)$ & $8.9(8.2,11.0)$ & $17.6(15.0,21.0)$ \\
\hline & 1st line $(n=65)$ & $44.6(32.3,57.5)$ & $10.8(6.9, \mathrm{NE})$ & $8.5(5.5,11.3)$ & $16.3(9.7,29.7)$ \\
\hline & 2nd line $(n=47)$ & $46.8(32.1,61.9)$ & $12.4(9.5, \mathrm{NE})$ & $9.5(6.9,13.7)$ & $19.9(15.0,25.8)$ \\
\hline & $\geq 2$ nd line $(n=81)^{b}$ & $45.7(34.6,57.1)$ & $11.1(0.5,18.5)$ & $10.9(8.2,12.7)$ & $19.7(15.0,21.0)$ \\
\hline \multirow{5}{*}{ Capmatinib } & Overall (cohorts $4,5 b, 6,7 ; n=160$ ) & $52.5^{\mathrm{a}}$ & NR & NR & NR \\
\hline & 1st line (cohort $5 b ; n=28)$ & $67.9(47.6,84.1)$ & $12.6(5.6, \mathrm{NE})$ & $12.4(8.2,23.4)$ & $20.8(12.4, \mathrm{NE})$ \\
\hline & 1st line (cohort $7 ; n=32)$ & $65.6(46.8-81.4)$ & $\mathrm{NE}^{\mathrm{d}}(5.5-\mathrm{NE})$ & $10.8^{\mathrm{d}}(6.9-\mathrm{NE})$ & $\mathrm{NE} \ddagger(10.6-\mathrm{NE})$ \\
\hline & 2nd line (cohort $6 ; n=31$ ) & $51.6(33.1,69.8)$ & $8.4(4.2, \mathrm{NE})$ & $6.9(4.2,13.3)$ & NR \\
\hline & $\geq 2$ nd line (cohort $4 ; n=69^{c}$ ) & $40.6(28.9,53.1)$ & $9.7(5.6,13.0)$ & $5.4(4.2,7.0)$ & $13.6(8.6,22.2)$ \\
\hline \multirow{5}{*}{ Savolitinib } & Overall $(n=70)$ & $42.9(31.1-55.3)$ & $8.3(5.3-16.6)$ & $6.8(4.2-9.6)$ & NR \\
\hline & $\operatorname{PSC}(n=25)$ & $40.0(21.1-61.3)$ & $17.9(4.1-\mathrm{NE})$ & $5.5(2.8-6.9)$ & NR \\
\hline & $\begin{array}{l}\text { Other NSCLC (mainly } \\
\text { adenocarcinoma; } n=45 \text { ) }\end{array}$ & $44.4(29.6-60.0)$ & $8.3(4.2-9.7)$ & $6.9(4.2-13.8)$ & NR \\
\hline & 1st line $(n=28)$ & $46.4(27.5-66.1)$ & $5.6(4.2-16.6)$ & $5.6(4.1-9.6)$ & NR \\
\hline & Previously treated $(n=42)$ & $40.5(25.6-56.7)$ & $9.7(4.9-\mathrm{NE})$ & $6.9(4.1-19.3)$ & NR \\
\hline
\end{tabular}

$\mathrm{CI}$, confidence interval; $\mathrm{mDOR}$, median duration of response; $M E T$, mesenchymal-epithelial transition; mOS, median overall survival; mPFS, median progression-free survival; NE, not estimable; NR, not reported; NSCLC, non-small-cell lung cancer; ORR, overall response rate; PSC, pulmonary sarcomatoid carcinoma; ${ }^{\ddagger}$, Not yet mature; ${ }^{a}$ Data not reported. Manually calculated from 1 CR, 18 PRs in Cohort $5 \mathrm{~b}$ (1st line), 21 PR in Cohort 7 (1st line), 28 PRs in Cohort 4 ( $\geq 2$ nd line) and 16 PRs in Cohort 6 (2nd line); 47 patients received tepotinib as second-line $(58 \%) ;{ }^{\mathrm{C}} 51$ patients received capmatinib as second-line $(73.9 \%) ;{ }^{\mathrm{d}}$ Data not mature at the data cutoff date.

\subsubsection{Capmatinib}

In the GEOMETRY mono-1 trial, a multicentre, open-label phase II study evaluated the efficacy and safety of capmatinib monotherapy in adult patients with EGFR wildtype, ALK-negative rearrangement, advanced NSCLC harbouring METex14 skipping mutations and/or MET amplification [35]. Patients with METex14 skipping mutations were assigned to cohorts 4 (previously treated patients) or $5 \mathrm{~b} / 7$ (treatment-naïve) and received $400 \mathrm{mg}$ capmatinib twice daily. The primary endpoint was ORR based on blinded independent review committee (BIRC) assessment per Response Evaluation Criteria in Solid Tumors (RECIST v1.1). The key secondary endpoint was DOR by BIRC. ORR in treatment-naïve patients $(n=60)$ was $67.9 \%$ for cohort $5 \mathrm{~b}$ and $65.6 \%$ for cohort 7 ; the combined ORR for treatment naïve patients was $66.7 \%$. Median DOR was 12.6 months for cohort $5 \mathrm{~b}$ (Table 2). Median DOR, PFS and OS for cohort 7 have not yet been reached. ORR in the previously treated patients $(n=69)$ was $40.6 \%$ and median DOR was 9.7 months. A clinically meaningful median OS of 20.8 months in first-line (Cohort 5b) and of 13.6 months in relapse settings (Cohort 4) was also observed [105].

Across all cohorts (364 patients), the most commonly reported AEs, regardless of causality, were peripheral edema ( $51 \% ; 9 \%$ grade 3 or 4$)$, nausea $(45 \%)$, vomiting $(28 \%)$, and increased creatinine (24\%; $0 \%$ grade 3 or 4 ) [35]. Grade $3 / 4$ TRAEs, regardless of causality, were reported in $67 \%$ of patients.

The U.S. Food and Drug Administration (FDA) granted accelerated approval to capmatinib for adult patients with metastatic METex14 NSCLC detected by an FDAapproved test.

\subsubsection{Savolitinib}

The efficacy and safety of savolitinib $600 \mathrm{mg}$ (bodyweight $\geq 50 \mathrm{~kg}$ ) or $400 \mathrm{mg}$ (bodyweight $<50 \mathrm{~kg}$ ) in unresectable or metastatic METex14 NSCLCs (40 (57\%) with adenocarcinoma, $25(36 \%)$ with PSC and $5(7 \%)$ with other NSCLC subtypes) were assessed in a multicentre, multi-cohort, single-arm phase II study [106]. At a median follow-up of 17.6 months, the IRC-assessed objective response rate was $42.9 \%$ (30 of 70 patients). The median time to response was 1.4 months, the median DOR was 8.3 months, and the disease control rate was $82.9 \%$ (72\% in PSC and $88.9 \%$ in other types of NSCLC). Seven 
(10\%) patients had a DOR that lasted 12 months or more. The median PFS was 6.8 months, and the 6-month and 12-month PFS was 52.0\% and 32\%, respectively. All 70 patients reported at least one TRAE. TRAEs of grade $\geq 3$ occurred in $32(46 \%)$ patients, the most frequent of which were increased aspartate aminotransferase $(n=13 \%)$, increased alanine aminotransferase $(10 \%)$, and peripheral edema $(n=9 \%)$. Treatment-related serious adverse events occurred in 17 (24\%) patients, the most common being abnormal hepatic function $(4 \%)$ and hypersensitivity $(2.9 \%)$.

Savolitinib has been granted conditional approval in China to treat patients with NSCLC with METex14 skipping alterations who have progressed following prior systemic therapy or are unable to receive chemotherapy.

In some countries, MET inhibitors are approved along with a companion diagnostic (CDx). The U.S. FDA has approved FoundationOne ${ }^{\circledR}$ Liquid CDx for use with capmatinib [107]. ArcherMET CDx was approved by the Japanese Ministry of Health to detect METex14 skipping alterations in tissue (RNA) and liquid biopsy for tepotinib. The U.S. FDA, however, has not specified a CDx for selecting eligible patients for tepotinib [108]. As current data indicate the efficacy of MET inhibitors as both first- and second-line therapy, the first-line choice should be based on patient characteristics (i.e., smoking status, comorbidities, and contraindications), disease characteristics (i.e., PD-L1 expression), as well as disease severity and the likelihood of fast rapid deterioration. In the Canadian context, one must also consider access to treatment and the balance between missed treatment opportunities while waiting to access MET-targeted therapy.

\subsection{Recommendations}

21. Patients with advanced METex14 NSCLC (non-squamous and squamous histology) that are eligible for treatment should be offered MET targeted therapy at some point during the course of their disease. Caution is needed when initiating a TKI post-ICI due to the potential increased risk of toxicity.

22. Although crizotinib has shown efficacy in patients with METex14 skipping mutations, regulatory approval for this indication was not sought. Due to more robust efficacy, type $1 \mathrm{~b} M E T$ inhibitors (tepotinib, capmatinib, or savolitinib) are preferred over crizotinib; however, crizotinib is listed on some provincial formularies and may be considered as an option if other therapies are unavailable.

23. The choice between type $1 \mathrm{~b} M E T$ inhibitors should be based on patient preference, toxicity profile, regulatory approvals, and access.

24. Patients with advanced METex14 NSCLC may be offered first line therapy with METtargeted therapy or other guideline-recommended standard of care approaches for patients without driver mutations. Based on current data with ICI in non-smokers and the evidence with MET inhibitors, an MET inhibitor is the preferred first-line therapy in non-smokers with NSCLC and METex14 skipping mutations.

25. For patients exposed to MET-targeted therapy, the guideline-recommended standard of care for advanced NSCLC patients without driver mutations should be offered as a subsequent line of treatment.

\subsection{What Are the Treatment Options for Metastatic NSCLC Patients with METex14 Skipping} Mutations and Brain Metastases?

Brain metastases may develop in up to $20-40 \%$ of patients with stage IV NSCLC [109], and the incidence among NSCLC patients with METex14 skipping mutations is similar [110]. Activity of therapy against brain metastases is essential for maintaining the best disease response and quality of life.

An open-label, phase II study indicated the efficacy of ICIs in PD-L1 positive (PD-L1 expression $\geq 1 \%$ ) stage IV NSCLC with brain metastasis, with $29.7 \%$ of patients achieving a response [111]. 93\% of patients were former or current smokers and 53\% had driver mutations (fourteen KRAS, six EGFR, and one each ALK, HER2, and METex14).

The efficacy of crizotinib in patients with brain metastases is limited due to poor brain penetration; in humans, a low CSF-to-plasma ratio (0.26 to 1) has been reported [112]. 
In the GEOMETRY mono-1 trial, fourteen patients with METex14 skipping mutations had brain metastases [35]. Intracranial responses to capmatinib were observed in seven of thirteen (54\%) evaluable patients, including complete resolution in four patients. Three of the seven patients with a response had received previous radiotherapy that could have contributed to response.

In the VISION trial (Cohort A), 23 patients had brain metastases at baseline, 15 of which were evaluable by the Response Assessment in Neuro-Oncology Brain Metastases (RANO-BM) criteria [113]. Twelve patients had received prior radiotherapy (2.6 to 44 weeks before study entry). Out of the seven patients with measurable disease, the intracranial best overall response (BOR) to tepotinib was 71\% (three of the five patients that responded had complete disappearance of the target lesions). Of eight patients with non-target lesions only, seven achieved intracranial disease control, and one had PD [113]. Moreover, case reports suggest a prolonged intracranial response to tepotinib in patients with symptomatic brain metastases from lung adenocarcinoma and MET alterations [114-116].

Data with capmatinib and tepotinib indicate that selective type $\mathrm{Ib} M E T$ inhibitors, which include tepotinib and capmatinib, are valid therapeutic options for NSCLC patients with brain metastases harbouring METex14 skipping mutations. As data is limited in determining the efficacy of MET inhibitors for treatment of brain metastases versus local therapies with radiation or surgery, these patients require multidisciplinary discussions to determine their optimal care.

\subsection{Recommendations}

26. For NSCLC patients with brain metastases harbouring METex14 skipping mutations, the type $\mathrm{Ib}$ MET inhibitors tepotinib and capmatinib may be considered as reasonable therapeutic options in addition to other multidisciplinary approaches. Such cases should be discussed with a multidisciplinary team including but not limited to radiation oncologists, neurosurgeons and medical oncologists.

\section{What Are the Preferred First-Line and Subsequent Therapies for Advanced NSCLC Patients with De Novo MET Amplification?}

The prevalence of high MET GCN gain and amplification carries a poor prognosis. Yet, due to challenges associated with the detection and reporting of MET amplification in NSCLC, studies assessing the efficacy of different therapeutic approaches in patients with de novo MET amplifications are sparse. About $15 \%$ to $20 \%$ of patients with METex 14 skipping mutations will also have an MET amplification [39,49]. This section will focus on patients without a concurrent METex14 skipping mutation. Current data indicate the impact of GCN on response to MET inhibitors (Table 3).

In a small series, the ORR with crizotinib differed dramatically between cases with different MET/CEP7 ratios (for a ratio of 1.8 to $\leq 2.2$, ORR $=0 \%$; for a ratio of $>2.2$ to $<5$, $\mathrm{ORR}=17 \%$; and for a ratio of $\geq 5, \mathrm{ORR}=67 \%$ ) [117]. One should keep in mind that $M E T / C E P 7 \geq 5$ represented only $0.34 \%$ of adenocarcinomas [82]. Out of seventeen patients with MET amplifications in the Cohort B of the METROS study (threshold MET/CEP7 > 2.2), six (35\%) achieved PR and six (35\%) SD with crizotinib [104].

In PROFILE 1001, the ORR in patients with high MET amplification category ( $\geq 4 M E T / C E P 7$ ratio) treated with crizotinib was $38.1 \%$, compared to $14 \%$ in patients with medium amplification category ( $>2.2$ to $<4 \mathrm{MET} / \mathrm{CEP7}$ ratio) [118]. Median DOR and median PFS in high MET amplification patients was 5.2 and 6.6 months, respectively, compared to a DOR of 3.8 and PFS of 1.9 months in patients in the medium category. MET amplification GCN $\geq 6$ was detected by NGS in fifteen of nineteen (78.9\%) patients. Of these, ORR was observed in six (40\%), two of whom had concurrent METex14 skipping mutations. No responses were observed among five patients with concurrent $K R A S, B R A F$, or EGFR mutations. 
Table 3. Trials with MET inhibitors in NSCLC with MET amplification.

\begin{tabular}{|c|c|c|c|c|c|c|c|}
\hline Drug & Trial & $\begin{array}{c}\text { MET Amplification Cut } \\
\text { Offs }\end{array}$ & $n$ & $\begin{array}{l}\text { Type of } \\
\text { Biopsy }\end{array}$ & $\begin{array}{r}\text { ORR, \% } \\
(95 \% \text { CI) }\end{array}$ & $\begin{array}{c}\text { Median DOR } \\
\text { Months } \\
\text { (95\% CI) }\end{array}$ & $\begin{array}{l}\text { Median PFS } \\
\text { Months } \\
(95 \% \text { CI })\end{array}$ \\
\hline \multirow{4}{*}{ Crizotinib } & \multirow{4}{*}{ PROFILE 1001} & $\begin{array}{c}M E T / C E P 7 \text { ratio: } \geq \\
\text { 4-High }\end{array}$ & 21 & \multirow{4}{*}{$\begin{array}{l}\text { Tumour } \\
\text { tissue }\end{array}$} & $38(18.1-61.6)$ & $5.2(3.3-25.8)$ & $6.7(3.4-9.2)$ \\
\hline & & $\begin{array}{l}\text { MET/CEP7 ratio: }>2.2 \text { to } \\
<4 \text {-Medium }\end{array}$ & 14 & & $14.3(1.8-42.8)$ & $3.8(3.8-3.8)$ & $1.9(1.3-5.6)$ \\
\hline & & $\begin{array}{c}M E T / C E P 7 \text { ratio: } \geq 1.8 \text { to } \\
\quad \leq 2.2 \text {-Low }\end{array}$ & 3 & & $33(0.8-90.6)$ & $12.2(12.2-12.2)$ & $1.8(0.8-14.0)$ \\
\hline & & $\mathrm{GCN} \geq 6$ & 15 & & $40 \%^{\mathrm{a}}$ & $4.86-12.02^{\mathrm{b}}$ & $0.85-14.9^{b}$ \\
\hline \multirow{4}{*}{ Capmatinib } & \multirow{4}{*}{ GEOMETRY-mono-1 } & Cohort 1a: GCN $\geq 10$ & 69 & \multirow{4}{*}{$\begin{array}{l}\text { Tumour } \\
\text { tissue }\end{array}$} & $29(19-41)$ & $8.3(4.2-15.4)$ & $4.1(2.9-4.8)$ \\
\hline & & Cohort $1 \mathrm{~b}$ : GCN 6 to $9^{c}$ & 42 & & $12(4-26)$ & $24.9(2.7-24.9)$ & $2.7(1.4-3.1)$ \\
\hline & & Cohort 2: GCN 4 or $5^{c}$ & 54 & & $9(3-20)$ & $9.7(4.2-\mathrm{NE})$ & $2.7(1.4-4.1)$ \\
\hline & & Cohort 3: GCN $<4^{\mathrm{c}}$ & 30 & & $7(1-22)$ & $4.2(4.2-4.2)$ & $3.6(2.2-4.2)$ \\
\hline Tepotinib & VISION & Cohort B: MET GCN >2.5 & 24 & $\begin{array}{l}\text { Liquid } \\
\text { biopsy }\end{array}$ & $41.7(22.1,63.4)$ & $\mathrm{NE}(2.8, \mathrm{NE})$ & $4.2(1.4, \mathrm{NE})$ \\
\hline
\end{tabular}

NE, not estimable; ${ }^{a} 95 \%$ CI not reported; ${ }^{b}$ Median not reported; ${ }^{\mathrm{c}}$ Closed for futility.

In GEOMETRY mono-1, cohorts with MET FISH GCN $\leq 9$ (Cohorts $1 \mathrm{~b}, 2$ and 3 ) were closed for futility (overall response $7-12 \%$ and OS $2.7-3.6$ months with capmatinib) at the interim analysis [35]. Capmatinib showed activity in patients with GCN $\geq 10$. ORR as assessed by the independent review committee was observed in $29 \%$ of 69 previously treated patients and in $40 \%$ of 15 patients who had not received previous treatment; however, the results were lower than the prespecified threshold for significance. Nevertheless, capmatinib was assessed by the independent review committee to have clinically relevant efficacy if a response was observed in at least $35 \%$ of the patients, with a lower boundary of the $95 \%$ confidence interval of more than $25 \%$. Median DOR was 8.3 months among twenty previously treated patients and 7.5 months among six patients who were treatment naive; the median PFS was 4.1 months and 4.2 months, respectively.

Cohort B of the VISION trial is currently assessing the efficacy of tepotinib in patients with $M E T$ amplification. The liquid biopsy analysis will include all subjects who tested positive for $M E T$ amplification in plasma ctDNA (GCN $\geq 2.5)$, irrespective of the tissue biopsy result. Two additional tissue biopsy analysis sets may be explored irrespective of the liquid biopsy test result: first, subjects with GCN gain $\geq 4$ and $<6$, and second, subjects with a GCN gain of $\geq 6$. The first analysis presented at ASCO 2021 included 24 patients with $M E T$ amplification detected by Guardant360 liquid biopsy assay with MET GCN $\geq 2.5$. Response rates in the seven patients that received tepotinib as first-line therapy was $42 \%$, and $30 \%$ in the ten patients that were treated using it as second-line [86].

Although preliminary evidence indicates activity of $M E T$ inhibitors in patients with NSCLC and MET amplification, the number of evaluated patients in these trials is small, duration of the follow-up is short, and the amplification thresholds are not clearly defined and vary between the trials. On the other hand, current standard of care approaches for patients without actionable mutations (ICIs \pm chemotherapy) lead to a median PFS of 8-9 months and a median OS of 16-30 months [91,119-122]. After discussing evolving data with MET inhibitors and evidence in support of ICIs \pm chemotherapy, the panel concluded that ICIs \pm chemotherapy should remain the standard of care in NSCLC with de novo MET amplification.

\section{Recommendations}

27. In patients with advanced NSCLC with de novo MET amplification, MET-targeted therapy could be considered through clinical trials at any line of therapy.

28. In patients with advanced NSCLC with de novo MET amplification, MET-targeted therapy could be considered after other standard therapies have been exhausted or in cases not eligible for standard therapies. 


\section{What Is the Preferred Therapy for Patients with Advanced EGFR-Mutated NSCLC with Acquired MET Amplification Progressing on EGFR Inhibitors?}

MET amplification is a potential resistance pattern to first- and second-generation EGFR inhibitors in NSCLC [50-52]. MET amplification is also recognized as a resistance mechanism to osimertinib in first- and subsequent-line therapy in patients with a T790M mutation. In the FLAURA trial, which evaluated first-line osimertinib in EGFR-mutated NSCLC patients [58], and the AURA3 trial, which evaluated osimertinib in patients with acquired T790M resistance [123], paired plasma samples were collected at baseline and at progression. MET amplification was detected in $15 \%$ of the paired samples following first-line osimertinib, and 19\% following progression on osimertinib in EGFR T790M positive patients.

As patients with MET amplification following osimertinib resistance tended to have inferior outcomes compared to patients without an increase in MET amplification [58], there is a need for effective strategies for patients who develop acquired resistance to osimertinib due to MET amplification. As MET amplification causes resistance to EGFR inhibitors by activation of an EGFR-independent pathway [58], targeting both EGFR and $M E T$ is required in order to overcome resistance to EGFR inhibitors.

A phase $\mathrm{Ib} / \mathrm{II}$ trial assessed the efficacy of capmatinib plus gefitinib in patients with EGFR-mutated, MET-dysregulated NSCLC who experienced disease progression while receiving first-generation EGFR inhibitors (gefitinib, $n=72$; erlotinib, $n=30$; and afatinib, $n=4$ ) [124]. The trial reported an ORR of $27 \%$, while a $47 \%$ ORR was reported among patients with high $M E T$ amplification ( $\geq 6 \mathrm{GCN})$.

The phase Ib/II INSIGHT trial [125] that compared tepotinib plus gefitinib versus tepotinib plus chemotherapy in patients with MET overexpression (high IHC3+ or medium IHC2+) or MET amplification with acquired resistance to EGFR inhibition (the majority of patients were exposed to first- or second-generation EGFR inhibitors and only 2 out of 73 received prior osimertinib), also reported benefit from dual MET and EGFR inhibition (mean GCN $\geq 5$ or MET/CEP7 ratio $\geq 2$ ). PFS and OS were longer with tepotinib plus gefitinib than with chemotherapy in patients with high (IHC3+) MET overexpression ( $n=34$; median PFS 8.3 months vs. 4.4 months; HR 0.35; median OS 37.3 months vs. 17.9 months; HR 0.33 ) or MET amplification ( $n=19$; median PFS 16.6 months versus 4.2 months; HR 0.13; median OS 37.3 months versus 13.1 months; HR 0.08). Although the trial was terminated early due to poor recruitment, these findings suggest improved antitumour activity for tepotinib plus gefitinib compared to standard chemotherapy in patients with EGFR-mutant NSCLC and MET amplification. The investigators also suggested that the use of liquid biopsy for detection of MET amplification instead of tissue biopsy could be a convenient and less invasive method that might improve trial recruitment.

In the phase $\mathrm{Ib}$ TATTON trial, $64 \%$ of patients with EGFR mutation-positive NSCLC and $M E T$-amplified tumours (MET/CEP7 ratio $\geq 2$ or mean GCN $\geq 5$ ) progressing on first-generation EGFR TKI responded to savolitinib plus osimertinib [126]. The response rate in patients progressing on osimertinib was 30\%. On the basis of the findings, two phase II trials are ongoing with savolitinib in patients with EGFR mutant-NSCLC with MET amplification and progression on previous osimertinib (SAVANNAH (NCT03778229) and ORCHARD (NCT03944772) trials). The phase II INSIGHT 2 study (NCT03940703) is currently investigating tepotinib plus osimertinib in patients with EGFR-mutant NSCLC with acquired resistance to prior EGFR TKIs due to MET amplification.

Recent data demonstrate promising activity of the combination of amivantamab, an EGFR-MET bispecific antibody, and lazertinib, a third-generation TKI, in both treatmentnaïve and osimertinib-relapsed patients with EGFR mutated NSCLC [127]. Osimertinibresistance mutations or amplifications in EGFR/MET were identified by NGS in both liquid and tumour biopsies. Of seventeen patients with EGFR and/or MET-based resistance, the ORR was $47 \%$, median DOR was 10.4 months, clinical benefit response rate was $82 \%$, and median PFS was 6.7 months. IHC staining for EGFR and MET expression was explored as a potential biomarker for response. Among ten patients whose tumours stained high for 
EGFR and MET expression, $90 \%$ had a tumour response. Additional validation analyses with both NGS and IHC are needed to confirm these promising preliminary data and to identify patients most likely to benefit from the amivantamab and lazertinib combination.

\section{Recommendations}

29. Patients with advanced EGFR-mutated NSCLC progressing on first and second generation EGFR TKIs without a T790M resistance mutation or patients progressing on osimertinib regardless of line of therapy and who have a MET amplification should be considered for clinical trials evaluating MET inhibitors.

\section{What Are Potential Strategies to Overcome Resistance to MET Inhibitors?}

Resistance mechanisms to MET TKIs are not well characterized. Acquired MET kinase domain mutations in residues D1228 and Y1230 confer resistance to type I MET TKIs in vitro by weakening chemical bonds between the drug and the MET kinase domain [128,129]. In addition, the solvent front G1163R mutation confers in vitro resistance to crizotinib but not to type Ib MET inhibitors like tepotinib, capmatinib, and savolitinib [130].

Analysis of twenty samples from patients with METex14 NSCLC with acquired resistance to a MET TKI revealed on-target resistance mediated by secondary MET kinase domain mutations and/or amplification in seven patients [131]. Off-target resistance, resulting from the activation of bypass signalling due to amplification of the ERBB family of receptor tyrosine kinase genes (BRAF amplification, KRAS amplification, and KRAS mutations), was detected in nine patients. One case displayed both on- and off-target mechanisms of resistance. In two patients with on-target resistant mutations, switching between type I and type II MET TKIs resulted in partial responses.

Data indicate that capmatinib has modest activity in crizotinib-pretreated MET-altered NSCLC [132]. Two out of twenty patients (fifteen patients with METex14 skipping mutation and five with $M E T$ amplification) achieved a partial response to capmatinib, and fourteen had SD, yielding a DCR of $80 \%$. Both patients with a partial response had received chemotherapy with pembrolizumab as intervening therapy between crizotinib and capmatinib. Among five patients who discontinued crizotinib for intolerance, DCR was $83 \%$, including two patients with best tumour shrinkage of $-25 \%$ and $-28 \%$. Intracranial DCR among four patients with measurable brain metastases was $100 \%$, with no observed intracranial objective responses. Overall, median PFS and OS were 5.5 months and 11.3 months, respectively. MET D1228 and Y1230 mutations and MAPK alterations were recurrently detected in post-crizotinib, pre-capmatinib plasma. The mutations persisted in plasma during treatment with capmatinib. New and persistent MET mutations and MAPK pathway alterations were detected in plasma at progression while on capmatinib, suggesting that capmatinib cannot easily overcome the secondary mutations.

In preclinical studies, class II MET TKIs (e.g., cabozantinib, merestinib, glesatinib) that bind to MET in a configuration that does not rely on interactions with the activation loop retained activity against MET D1228 and Y1230 mutations [58]. These observations have been confirmed by clinical case reports [133]. Ongoing studies with merestinib (NCT02920996) and cabozantinib (NCT03911193) in MET TKI-pretreated patients may help answer whether preclinical sensitivity consistently translates into clinical response.

Based on current evidence, in the context of on-target resistance, additional METtargeted strategies employing MET antibodies or MET antibody-drug conjugates should be explored prospectively through clinical studies [134-136]. Initial data from the phase I CHRYSALIS study evaluating amivantamab in patients with METex14 skipping mutations showed anti-tumour activity in treatment-naïve and previously-treated patients, including patients previously treated with $M E T$ inhibitors [137]. For off-target mutations, combining $M E T$ inhibitors with another targeted therapy seems to be an appropriate approach that requires further study. 


\section{Recommendations}

30. Patients with advanced NSCLC MET alterations (either METex14 skipping and amplifications) resistant to $M E T$ inhibitors should be encouraged to enroll in clinical trials whenever possible. Patients progressing on type I MET inhibitors may be candidates for clinical trials with type II MET inhibitors or combination therapies.

31. There is currently no evidence that resistance profiling of the tumour post-METtargeted therapy impacts patient outcomes; therefore, it is not recommended outside of clinical trials.

\section{Conclusions}

Lung cancer patients presenting with $M E T$ alterations represent a diverse population regarding their clinical presentation, underlying histology, and genomic instability. As with other driver mutations, timely detection and initiation of appropriate treatment are key to optimizing outcomes. MET inhibitors are emerging as effective and safe options for patients with METex14 skipping mutations; however, their sequencing, among other available options, requires further study. Participation in clinical trials is recommended for patients with $M E T$ amplification because of unanswered questions including optimal assays and cut-offs, as well as other clinicopathological characteristics of these patients that might be implicated in therapeutic decision making. Upcoming results from ongoing clinical trials and the emergence of novel agents and combinations will further streamline the management of patients with MET-altered NSCLC.

Author Contributions: Conceptualization, P.K.C.; Writing-original draft preparation, P.K.C.; Writing-review and editing, P.K.C., S.O.B., N.B., Q.S.-C.C., P.D., R.A.J., N.B.L., B.S.S., P.F.W.-P. and B.L.M.; Funding acquisition, P.K.C. All authors have read and agreed to the published version of the manuscript.

Funding: Funding for the development and publishing of this manuscript (expert panel meetings, medical writing support, and journal submission support) was provided by EMD Serono in the form of an unrestricted educational grant. The funder did not participate in expert panel meetings (was not present) and had no role in the writing, editing and submission of the manuscript.

Institutional Review Board Statement: Not applicable. The recommendations herein are based on literature and expert opinion, and were not formulated using humans or animals.

Informed Consent Statement: Not applicable. The recommendations herein are based on literature and expert opinion, and were not formulated using humans or animals.

Data Availability Statement: The data discussed herein are available within the article and its references.

Acknowledgments: The program/project logistics were managed by RDCG Inc. Medical writing support was provided by Radmila Day (RDCG Inc.) and journal submission support was provided by Gabriele Colasurdo (RDCG Inc.).

Conflicts of Interest: P.K.C. has received honoraria and/or has participated in advisory board meetings with Amgen, AstraZeneca, Bayer, Bristol-Myers-Squibb, EMD Serono, Merck, Novartis, Pfizer, Roche and Takeda. S.O.B. has participated in advisory board meetings with AstraZeneca, Bayer, Bristol-Myers-Squibb, EMD Serono, Merck, Novartis, Pfizer, Roche, and Takeda, and has received grant funding from AstraZeneca, CancerCare Manitoba Foundation, and Genome Canada. N.B. has participated in advisory board meetings with EMD Serono, Novartis and Pfizer. Q.S.-C. has received honoraria and/or has participated in advisory board meetings with AbbVie, Amgen, Astellas, AstraZeneca, Boehringer Ingelheim, Bristol Myers Squibb, Eli Lilly, Merck, Novartis, Pfizer, Roche, and Takeda, has received educational grant support from Bristol Myers Squibb, has received research funding from AstraZeneca and Exactis, and has received clinical trial research funding from Alkermes, Amgen, Apollomics, Astellas, AstraZeneca, Boehringer Ingelheim, Bicycle, Bristol Myers Squibb, Debiopharm, Eli Lilly, Epizyme, GlaxoSmithKline, Ocellaris, Pfizer, Spectrum, Turning Point Therapeutics, Treadwell, and VelosBio. P.D. has participated in advisory board meetings with AstraZeneca, Eli Lilly, and Pfizer, has provided presentations for AstraZeneca and Pfizer, and has received research funding from AstraZeneca, Bayer, Eli Lilly, EMD Serono, Pfizer, Novartis, and 
Roche. R.A.J. has participated on advisory boards for AbbVie, Amgen, AstraZeneca, Bayer, BristolMyers Squibb, EMD Serono, Fusion Pharmaceuticals, Jazz Pharmaceuticals, Lilly, Merck Sharp \& Dohme, Novartis, Pfizer, Roche Canada, Sanofi/Regeneron, and Takeda, has received honoraria from Amgen, AstraZeneca, Bristol-Myers Squibb, Merck Sharp \& Dohme, Novartis Pharmaceuticals Canada, and Roche Canada, and has received research funding from AstraZeneca/MedImmune, Bristol-Myers Squibb, Debiopharm Group, Merck Sharp \& Dohme, Novartis and Turnstone Bio. N.B.L. has received honoraria and has participated in advisory board meetings with Xcovery, has received honoraria or travel expenses (or both) for independent continuing medical education lectures from AstraZeneca, Bristol-Myers Squibb, Merck Sharp \& Dohme, Roche, and Pfizer, and reports institutional research funding from AstraZeneca, Array, Guardant, Merck Sharp \& Dohme, and Roche. B.S.S. has participated in advisory board meetings with Amgen, AstraZeneca, Bayer, Eli Lilly, Janssen, Merck, Novartis, Pfizer, and Roche, has received honoraria from Amgen, AstraZeneca, Bayer, Boehringer Ingelheim, EMD Serono, Merck, Novartis, Pfizer, Roche, and Thermo Fisher, has received grant support from AstraZeneca, Biocartis, Boehringer Ingelheim, Eli Lilly, EMD Serono, Novartis, Pfizer, Roche, and Thermo Fisher, and has received research funding from AstraZeneca, Biocartis, Boehringer Ingelheim, Eli Lilly, EMD Serono, Novartis, Pfizer, Roche, and Thermo Fisher. In the last 24 months, P.F.W.-P. has received honoraria and/or has participated in advisory board meetings with AstraZeneca, Bayer, Bristol-Myers Squibb, EMD Serono, Merck, Novartis, Pfizer, and Sanofi. B.M. has received honoraria and/or has participated in advisory board meetings with AstraZeneca, Bayer, Boehringer Ingelheim, Bristol-Myers Squibb, Janssen, Merck, Novartis, Pfizer, and Roche.

\section{References}

1. Siegel, R.L.; Miller, K.D.; Fuchs, H.E.; Jemal, A. Cancer Statistics. CA Cancer J. Clin. 2021, 71, 7-33. [CrossRef] [PubMed]

2. Cooper, C.S.; Park, M.; Blair, D.G.; Tainsky, M.A.; Huebner, K.; Croce, C.M.; Vande Woude, G.F. Molecular cloning of a new transforming gene from a chemically transformed human cell line. Nature 1984, 311, 29-33. [CrossRef] [PubMed]

3. Schmidt, L.; Duh, F.M.; Chen, F.; Kishida, T.; Glenn, G.; Choyke, P.; Scherer, S.W.; Zhuang, Z.; Lubensky, I.; Dean, M.; et al. Germline and somatic mutations in the tyrosine kinase domain of the MET proto-oncogene in papillary renal carcinomas. Nat. Genet. 1997, 16, 68-73. [CrossRef]

4. Furlan, A.; Kherrouche, Z.; Montagne, R.; Copin, M.C.; Tulasne, D. Thirty years of research on met receptor to move a biomarker from bench to bedside. Cancer Res. 2014, 74, 6737-6744. [CrossRef] [PubMed]

5. Recondo, G.; Che, J.; Jänne, P.A.; Awad, M.M. Targeting MET Dysregulation in Cancer. Cancer Discov. 2020, 10, 922-934. [CrossRef]

6. Drilon, A.; Cappuzzo, F.; Ou, S.I.; Camidge, D.R. Targeting MET in Lung Cancer: Will Expectations Finally Be MET? J. Thorac. Oncol. 2017, 12, 15-26. [CrossRef]

7. Liu, S.; Meric-Bernstam, F.; Parinyanitikul, N.; Wang, B.; Eterovic, A.K.; Zheng, X.; Gagea, M.; Chavez-MacGregor, M.; Ueno, N.T.; Lei, X.; et al. Functional consequence of the MET-T1010I polymorphism in breast cancer. Oncotarget 2015, 6, 2604-2614. [CrossRef]

8. de Melo Gagliato, D.; Jardim, D.L.; Falchook, G.; Tang, C.; Zinner, R.; Wheler, J.J.; Janku, F.; Subbiah, V.; Piha-Paul, S.A.; Fu, S.; et al. Analysis of MET genetic aberrations in patients with breast cancer at MD Anderson Phase I unit. Clin. Breast Cancer 2014, 14, 468-474. [CrossRef] [PubMed]

9. Neklason, D.W.; Done, M.W.; Sargent, N.R.; Schwartz, A.G.; Anton-Culver, H.; Griffin, C.A.; Ahnen, D.J.; Schildkraut, J.M.; Tomlinson, G.E.; Strong, L.C.; et al. Activating mutation in MET oncogene in familial colorectal cancer. BMC Cancer 2011, 11, 424. [CrossRef]

10. Cheng, F.; Guo, D. MET in glioma: Signaling pathways and targeted therapies. J. Exp. Clin. Cancer Res. 2019, 38, 270. [CrossRef] [PubMed]

11. Stella, G.M.; Benvenuti, S.; Gramaglia, D.; Scarpa, A.; Tomezzoli, A.; Cassoni, P.; Senetta, R.; Venesio, T.; Pozzi, E.; Bardelli, A.; et al. MET mutations in cancers of unknown primary origin (CUPs). Human Mutat. 2011, 32, 44-50. [CrossRef]

12. Tovar, E.A.; Graveel, C.R. MET in human cancer: Germline and somatic mutations. Ann. Transl. Med. 2017, 5, 205. [CrossRef]

13. Organ, S.L.; Tsao, M.S. An overview of the c-MET signaling pathway. Ther. Adv. Med. Oncol. 2011, 3 (Suppl. S1), S7-S19. [CrossRef] [PubMed]

14. Boccaccio, C.; Andò, M.; Tamagnone, L.; Bardelli, A.; Michieli, P.; Battistini, C.; Comoglio, P.M. Induction of epithelial tubules by growth factor HGF depends on the STAT pathway. Nature 1998, 391, 285-288. [CrossRef] [PubMed]

15. Skead, G.; Govender, D. Gene of the month: MET. J. Clin. Pathol. 2015, 68, 405-409. [CrossRef] [PubMed]

16. Castiglione, R.; Alidousty, C.; Holz, B.; Wagener, S.; Baar, T.; Heydt, C.; Binot, E.; Zupp, S.; Kron, A.; Wolf, J.; et al. Comparison of the genomic background of MET-altered carcinomas of the lung: Biological differences and analogies. Mod. Pathol. 2019, 32, 627-638. [CrossRef] [PubMed]

17. Russo, A.; Lopes, A.R.; McCusker, M.G.; Garrigues, S.G.; Ricciardi, G.R.; Arensmeyer, K.E.; Scilla, K.A.; Mehra, R.; Rolfo, C. New Targets in Lung Cancer (Excluding EGFR, ALK, ROS1). Curr. Oncol. Rep. 2020, 22, 48. [CrossRef] [PubMed]

18. Lamberti, G.; Andrini, E.; Sisi, M.; Rizzo, A.; Parisi, C.; Di Federico, A.; Gelsomino, F.; Ardizzoni, A. Beyond EGFR, ALK and ROS1: Current evidence and future perspectives on newly targetable oncogenic drivers in lung adenocarcinoma. Crit. Rev. Oncol. Hematol. 2020, 156, 103119. [CrossRef] [PubMed] 
19. Frampton, G.M.; Ali, S.M.; Rosenzweig, M.; Chmielecki, J.; Lu, X.; Bauer, T.M.; Akimov, M.; Bufill, J.A.; Lee, C.; Jentz, D.; et al. Activation of MET via diverse exon 14 splicing alterations occurs in multiple tumor types and confers clinical sensitivity to MET inhibitors. Cancer Discov. 2015, 5, 850-859. [CrossRef]

20. Awad, M.M.; Oxnard, G.R.; Jackman, D.M.; Savukoski, D.O.; Hall, D.; Shivdasani, P.; Heng, J.C.; Dahlberg, S.E.; Jänne, P.A.; Verma, S.; et al. MET Exon 14 Mutations in Non-Small-Cell Lung Cancer Are Associated with Advanced Age and Stage-Dependent MET Genomic Amplification and c-Met Overexpression. J. Clin. Oncol. 2016, 34, 721-730. [CrossRef]

21. Schrock, A.B.; Frampton, G.M.; Suh, J.; Chalmers, Z.R.; Rosenzweig, M.; Erlich, R.L.; Halmos, B.; Goldman, J.; Forde, P.; Leuenberger, K.; et al. Characterization of 298 Patients with Lung Cancer Harboring MET Exon 14 Skipping Alterations. J. Thorac. Oncol. 2016, 11, 1493-1502. [CrossRef]

22. Liang, H.; Wang, M. MET Oncogene in Non-Small Cell Lung Cancer: Mechanism of MET Dysregulation and Agents Targeting the HGF/c-Met Axis. Onco. Targets Ther. 2020, 13, 2491-2510. [CrossRef]

23. Dagogo-Jack, I.; Yoda, S.; Lennerz, J.K.; Langenbucher, A.; Lin, J.J.; Rooney, M.M.; Prutisto-Chang, K.; Oh, A.; Adams, N.A.; Yeap, B.Y.; et al. MET Alterations Are a Recurring and Actionable Resistance Mechanism in ALK-Positive Lung Cancer. Clin. Cancer Res. 2020, 26, 2535-2545. [CrossRef] [PubMed]

24. Sadiq, A.A.; Salgia, R. MET as a possible target for non-small-cell lung cancer. J. Clin. Oncol. 2013, 31, 1089-1096. [CrossRef] [PubMed]

25. Mignard, X.; Ruppert, A.M.; Antoine, M.; Vasseur, J.; Girard, N.; Mazières, J.; Moro-Sibilot, D.; Fallet, V.; Rabbe, N.; Thivolet-Bejui, F.; et al. c-MET Overexpression as a Poor Predictor of MET Amplifications or Exon 14 Mutations in Lung Sarcomatoid Carcinomas. J. Thorac. Oncol. 2018, 13, 1962-1967. [CrossRef] [PubMed]

26. Guo, R.; Berry, L.D.; Aisner, D.L.; Sheren, J.; Boyle, T.; Bunn, P.A., Jr.; Johnson, B.E.; Kwiatkowski, D.J.; Drilon, A.; Sholl, L.M.; et al. MET IHC Is a Poor Screen for MET Amplification or MET Exon 14 Mutations in Lung Adenocarcinomas: Data from a Tri-Institutional Cohort of the Lung Cancer Mutation Consortium. J. Thorac. Oncol. 2019, 14, 1666-1671. [CrossRef]

27. Shaw, A.T.; Engelman, J.A. ALK in lung cancer: Past, present, and future. J. Clin. Oncol. 2013, 31, 1105-1111. [CrossRef] [PubMed]

28. Sabari, J.K.; Leonardi, G.C.; Shu, C.A.; Umeton, R.; Montecalvo, J.; Ni, A.; Chen, R.; Dienstag, J.; Mrad, C.; Bergagnini, I.; et al. PD-L1 expression, tumor mutational burden, and response to immunotherapy in patients with MET exon 14 altered lung cancers. Ann. Oncol. 2018, 29, 2085-2091. [CrossRef] [PubMed]

29. Travis, W.D.; Brambilla, E.; Nicholson, A.G.; Yatabe, Y.; Austin, J.; Beasley, M.B.; Chirieac, L.R.; Dacic, S.; Duhig, E.; Flieder, D.B.; et al. The 2015 World Health Organization Classification of Lung Tumors: Impact of Genetic, Clinical and Radiologic Advances Since the 2004 Classification. J. Thorac. Oncol. 2015, 10, 1243-1260. [CrossRef] [PubMed]

30. Liu, X.; Jia, Y.; Stoopler, M.B.; Shen, Y.; Cheng, H.; Chen, J.; Mansukhani, M.; Koul, S.; Halmos, B.; Borczuk, A.C. Next-Generation Sequencing of Pulmonary Sarcomatoid Carcinoma Reveals High Frequency of Actionable MET Gene Mutations. J. Clin. Oncol. 2016, 34, 794-802. [CrossRef]

31. Saffroy, R.; Fallet, V.; Girard, N.; Mazieres, J.; Sibilot, D.M.; Lantuejoul, S.; Rouquette, I.; Thivolet-Bejui, F.; Vieira, T.; Antoine, M.; et al. MET exon 14 mutations as targets in routine molecular analysis of primary sarcomatoid carcinoma of the lung. Oncotarget 2017, 8, 42428-42437. [CrossRef]

32. Schrock, A.B.; Li, S.D.; Frampton, G.M.; Suh, J.; Braun, E.; Mehra, R.; Buck, S.C.; Bufill, J.A.; Peled, N.; Karim, N.A.; et al. Pulmonary Sarcomatoid Carcinomas Commonly Harbor Either Potentially Targetable Genomic Alterations or High Tumor Mutational Burden as Observed by Comprehensive Genomic Profiling. J. Thorac. Oncol. 2017, 12, 932-942. [CrossRef]

33. Liu, X.W.; Chen, X.R.; Rong, Y.M.; Lyu, N.; Xu, C.W.; Wang, F.; Sun, W.Y.; Fang, S.G.; Yuan, J.P.; Wang, H.J.; et al. MET exon 14 skipping mutation, amplification and overexpression in pulmonary sarcomatoid carcinoma: A multi-center study. Transl. Oncol. 2020, 13, 100868. [CrossRef]

34. Lam, V.K.; Tran, H.T.; Banks, K.C.; Lanman, R.B.; Rinsurongkawong, W.; Peled, N.; Lewis, J.; Lee, J.J.; Roth, J.; Roarty, E.B.; et al. Targeted Tissue and Cell-Free Tumor DNA Sequencing of Advanced Lung Squamous-Cell Carcinoma Reveals Clinically Significant Prevalence of Actionable Alterations. Clin. Lung Cancer 2019, 20, 30-36. [CrossRef]

35. Wolf, J.; Seto, T.; Han, J.Y.; Reguart, N.; Garon, E.B.; Groen, H.; Tan, D.; Hida, T.; de Jonge, M.; Orlov, S.V.; et al. Capmatinib in MET Exon 14-Mutated or MET-Amplified Non-Small-Cell Lung Cancer. N. Engl. J. Med. 2020, 383, 944-957. [CrossRef]

36. Paik, P.K.; Felip, E.; Veillon, R.; Sakai, H.; Cortot, A.B.; Garassino, M.C.; Mazieres, J.; Viteri, S.; Senellart, H.; Van Meerbeeck, J.; et al. Tepotinib in Non-Small-Cell Lung Cancer with MET Exon 14 Skipping Mutations. N. Engl. J. Med. 2020, 383, 931-943. [CrossRef]

37. Salgia, R.; Sattler, M.; Scheele, J.; Stroh, C.; Felip, E. The promise of selective MET inhibitors in non-small cell lung cancer with MET exon 14 skipping. Cancer Treat. Rev. 2020, 87, 102022. [CrossRef]

38. Tong, J.H.; Yeung, S.F.; Chan, A.W.; Chung, L.Y.; Chau, S.L.; Lung, R.W.; Tong, C.Y.; Chow, C.; Tin, E.K.; Yu, Y.H.; et al. MET Amplification and Exon 14 Splice Site Mutation Define Unique Molecular Subgroups of Non-Small Cell Lung Carcinoma with Poor Prognosis. Clin. Cancer Res. 2016, 22, 3048-3056. [CrossRef] [PubMed]

39. Lee, G.D.; Lee, S.E.; Oh, D.Y.; Yu, D.B.; Jeong, H.M.; Kim, J.; Hong, S.; Jung, H.S.; Oh, E.; Song, J.Y.; et al. MET Exon 14 Skipping Mutations in Lung Adenocarcinoma: Clinicopathologic Implications and Prognostic Values. J. Thorac. Oncol. 2017, 12, 1233-1246. [CrossRef] [PubMed] 
40. Awad, M.M.; Leonardi, G.C.; Kravets, S.; Dahlberg, S.E.; Drilon, A.E.; Noonan, S.; Camidge, D.R.; Ou, S.I.; Costa, D.B.; Gadgeel, S.M.; et al. Impact of MET inhibitors on survival among patients (pts) with MET exon 14 mutant (METdel14) non-small cell lung cancer (NSCLC). J. Clin. Oncol. 2017, 35, 8511. [CrossRef]

41. Mazieres, J.; Drilon, A.; Lusque, A.; Mhanna, L.; Cortot, A.B.; Mezquita, L.; Thai, A.A.; Mascaux, C.; Couraud, S.; Veillon, R.; et al. Immune checkpoint inhibitors for patients with advanced lung cancer and oncogenic driver alterations: Results from the IMMUNOTARGET registry. Ann. Oncol. 2019, 30, 1321-1328. [CrossRef] [PubMed]

42. Hur, J.Y.; Ku, B.M.; Shim, J.H.; Jung, H.A.; Sun, J.M.; Lee, S.H.; Ahn, J.S.; Park, K.; Ahn, M.J. Characteristics and Clinical Outcomes of Non-small Cell Lung Cancer Patients in Korea with MET Exon 14 Skipping. In Vivo 2020, 34, 1399-1406. [CrossRef] [PubMed]

43. Digumarthy, S.R.; Mendoza, D.P.; Zhang, E.W.; Lennerz, J.K.; Heist, R.S. Clinicopathologic and Imaging Features of Non-SmallCell Lung Cancer with MET Exon 14 Skipping Mutations. Cancers 2019, 11, 2033. [CrossRef]

44. Cappuzzo, F.; Marchetti, A.; Skokan, M.; Rossi, E.; Gajapathy, S.; Felicioni, L.; Del Grammastro, M.; Sciarrotta, M.G.; Buttitta, F.; Incarbone, M.; et al. Increased MET gene copy number negatively affects survival of surgically resected non-small-cell lung cancer patients. J. Clin. Oncol. 2009, 27, 1667-1674. [CrossRef]

45. Casadevall, D.; Gimeno, J.; Clavé, S.; Taus, Á.; Pijuan, L.; Arumí, M.; Lorenzo, M.; Menéndez, S.; Cañadas, I.; Albanell, J.; et al. MET expression and copy number heterogeneity in nonsquamous non-small cell lung cancer (nsNSCLC). Oncotarget 2015, 6, 16215-16226. [CrossRef]

46. Watermann, I.; Schmitt, B.; Stellmacher, F.; Müller, J.; Gaber, R.; Kugler, C.h.; Reinmuth, N.; Huber, R.M.; Thomas, M.; Zabel, P.; et al. Improved diagnostics targeting c-MET in non-small cell lung cancer: Expression, amplification and activation? Diagn. Pathol. 2015, 10, 130. [CrossRef]

47. Collisson, E.A.; Campbell, J.D.; Brooks, A.N.; Berger, A.H.; Lee, W.; Chmielecki, J.; Beer, D.G.; Cope, L.; Creighton, C.J.; Danilova, L.; et al. Comprehensive molecular profiling of lung adenocarcinoma. Nature 2014, 511, 543-550. [CrossRef]

48. Go, H.; Jeon, Y.K.; Park, H.J.; Sung, S.W.; Seo, J.W.; Chung, D.H. High MET gene copy number leads to shorter survival in patients with non-small cell lung cancer. J. Thorac. Oncol. 2010, 5, 305-313. [CrossRef]

49. Kron, A.; Scheffler, M.; Heydt, C.; Ruge, L.; Schaepers, C.; Eisert, A.K.; Merkelbach-Bruse, S.; Riedel, R.; Nogova, L.; Fischer, R.N.; et al. Genetic Heterogeneity of MET-Aberrant NSCLC and Its Impact on the Outcome of Immunotherapy. J. Thorac. Oncol. 2021, 16, 572-582. [CrossRef]

50. Jardim, D.L.; Tang, C.; Gagliato, D.; Falchook, G.S.; Hess, K.; Janku, F.; Fu, S.; Wheler, J.J.; Zinner, R.G.; Naing, A.; et al. Analysis of 1,115 patients tested for MET amplification and therapy response in the MD Anderson Phase I Clinic. Clin. Cancer Res. 2014, 20, 6336-6345. [CrossRef]

51. Lennerz, J.K.; Kwak, E.L.; Ackerman, A.; Michael, M.; Fox, S.B.; Bergethon, K.; Lauwers, G.Y.; Christensen, J.G.; Wilner, K.D.; Haber, D.A.; et al. MET amplification identifies a small and aggressive subgroup of esophagogastric adenocarcinoma with evidence of responsiveness to crizotinib. J. Clin. Oncol. 2011, 29, 4803-4810. [CrossRef]

52. Tartarone, A.; Lerose, R. Clinical approaches to treat patients with non-small cell lung cancer and epidermal growth factor receptor tyrosine kinase inhibitor acquired resistance. Ther. Adv. Respir. Dis. 2015, 9, 242-250. [CrossRef] [PubMed]

53. Juchum, M.; Günther, M.; Laufer, S.A. Fighting cancer drug resistance: Opportunities and challenges for mutation-specific EGFR inhibitors. Drug Resist. Updat. 2015, 20, 12-28. [CrossRef]

54. Remon, J.; Morán, T.; Majem, M.; Reguart, N.; Dalmau, E.; Márquez-Medina, D.; Lianes, P. Acquired resistance to epidermal growth factor receptor tyrosine kinase inhibitors in EGFR-mutant non-small cell lung cancer: A new era begins. Cancer Treat. Rev. 2014, 40, 93-101. [CrossRef]

55. Mok, T.S.; Wu, Y.; Ahn, M.; Garassino, M.C.; Kim, H.R.; Ramalingam, S.S.; Shepherd, F.A.; He, Y.; Akamatsu, H.; Theelen, W.S.; et al. Osimertinib or Platinum-Pemetrexed in EGFR T790M-Positive Lung Cancer. N. Engl. J. Med. 2017, 376, 629-640. [CrossRef]

56. Helman, E.; Nguyen, M.; Karlovich, C.A.; Despain, D.; Choquette, A.K.; Spira, A.I.; Yu, H.A.; Camidge, D.R.; Harding, T.C.; Lanman, R.B.; et al. Cell-Free DNA Next-Generation Sequencing Prediction of Response and Resistance to Third-Generation EGFR Inhibitor. Clin. Lung Cancer 2018, 19, 518-530. [CrossRef]

57. Chabon, J.J.; Simmons, A.D.; Lovejoy, A.F.; Esfahani, M.S.; Newman, A.M.; Haringsma, H.J.; Kurtz, D.M.; Stehr, H.; Scherer, F.; Karlovich, C.A.; et al. Circulating tumour DNA profiling reveals heterogeneity of EGFR inhibitor resistance mechanisms in lung cancer patients. Nat. Commun. 2016, 7, 11815. [CrossRef] [PubMed]

58. Ramalingam, S.S.; Cheng, Y.; Zhou, C.; Ohe, Y.; Imamura, F.; Cho, B.C.; Lin, M.-C.; Majem, M.; Shah, R.; Rukazenkov, Y.; et al. Mechanisms of acquired resistance to first-line osimertinib: Preliminary data from the phase III FLAURA study. Ann. Oncol. 2018, 29, viii740. [CrossRef]

59. Engelman, J.A.; Zejnullahu, K.; Mitsudomi, T.; Song, Y.; Hyland, C.; Park, J.O.; Lindeman, N.; Gale, C.M.; Zhao, X.; Christensen, J.; et al. MET amplification leads to gefitinib resistance in lung cancer by activating ERBB3 signaling. Science 2017, 316, 1039-1043. [CrossRef]

60. Wang, Y.; Li, L.; Han, R.; Jiao, L.; Zheng, J.; He, Y. Clinical analysis by next-generation sequencing for NSCLC patients with MET amplification resistant to osimertinib. Lung Cancer 2018, 118, 105-110. [CrossRef] [PubMed]

61. Nguyen, H.N.; Cao, N.T.; Van Nguyen, T.C.; Le, K.; Nguyen, D.T.; Nguyen, Q.T.; Nguyen, T.T.; Van Nguyen, C.; Le, H.T.; Nguyen, M.T.; et al. Liquid biopsy uncovers distinct patterns of DNA methylation and copy number changes in NSCLC patients with different EGFR-TKI resistant mutations. Sci. Rep. 2021, 11, 16436. [CrossRef] [PubMed] 
62. Baldacci, S.; Figeac, M.; Antoine, M.; Descarpentries, C.; Kherrouche, Z.; Jamme, P.; Copin, M.C.; Tulasne, D.; Nanni, I.; Beau-Faller, M.; et al. High MET Overexpression Does Not Predict the presence of MET exon 14 Splice Mutations in NSCLC: Results from the IFCT PREDICT.amm study. J. Thorac. Oncol. 2020, 15, 120-124. [CrossRef]

63. Tan, A.C.; Lai, G.; Tan, G.S.; Poon, S.Y.; Doble, B.; Lim, T.H.; Aung, Z.W.; Takano, A.; Tan, W.L.; Ang, M.K.; et al. Utility of incorporating next-generation sequencing (NGS) in an Asian non-small cell lung cancer (NSCLC) population: Incremental yield of actionable alterations and cost-effectiveness analysis. Lung Cancer 2020, 139, 207-215. [CrossRef] [PubMed]

64. Bai, R.; Lv, Z.; Xu, D.; Cui, J. Predictive biomarkers for cancer immunotherapy with immune checkpoint inhibitors. Biomark. Res. 2020, 8, 34. [CrossRef] [PubMed]

65. Lindeman, N.I.; Cagle, P.T.; Aisner, D.L.; Arcila, M.E.; Beasley, M.B.; Bernicker, E.H.; Colasacco, C.; Dacic, S.; Hirsch, F.R.; Kerr K.; et al. Updated Molecular Testing Guideline for the Selection of Lung Cancer Patients for Treatment with Targeted Tyrosine Kinase Inhibitors: Guideline from the College of American Pathologists, the International Association for the Study of Lung Cancer, and the Association for Molecular Pathology. J. Mol. Diagn. 2018, 20, 129-159. [CrossRef]

66. Kalemkerian, G.P.; Narula, N.; Kennedy, E.B.; Biermann, W.A.; Donington, J.; Leighl, N.B.; Lew, M.; Pantelas, J.; Ramalingam, S.S.; Reck, M.; et al. Molecular Testing Guideline for the Selection of Patients With Lung Cancer for Treatment With Targeted Tyrosine Kinase Inhibitors: American Society of Clinical Oncology Endorsement of the College of American Pathologists/International Association for the Study of Lung Cancer/Association for Molecular Pathology Clinical Practice Guideline Update. J. Clin. Oncol. 2018, 36, 911-919. [CrossRef] [PubMed]

67. Planchard, D.; Popat, S.; Kerr, K.; Novello, S.; Smit, E.F.; Faivre-Finn, C.; Mok, T.S.; Reck, M.; Van Schil, P.E.; Hellmann, M.D.; et al. Metastatic non-small cell lung cancer: ESMO Clinical Practice Guidelines for diagnosis, treatment and follow-up. Ann. Oncol. 2018, 29, iv192-iv237. [CrossRef]

68. Thunnissen, E.; Weynand, B.; Udovicic-Gagula, D.; Brcic, L.; Szolkowska, M.; Hofman, P.; Smojver-Ježek, S.; Anttila, S.; Calabrese, F.; Kern, I.; et al. Lung cancer biomarker testing: Perspective from Europe. Transl. Lung Cancer Res. 2020, 9, 887-897. [CrossRef]

69. Yip, S.; Christofides, A.; Banerji, S.; Downes, M.R.; Izevbaye, I.; Lo, B.; MacMillan, A.; McCuaig, J.; Stockley, T.; Yousef, G.M.; et al. A Canadian guideline on the use of next-generation sequencing in oncology. Curr. Oncol. 2019, 26, e241-e254. [CrossRef]

70. Melosky, B.; Blais, N.; Cheema, P.; Couture, C.; Juergens, R.; Kamel-Reid, S.; Tsao, M.S.; Wheatley-Price, P.; Xu, Z.; Ionescu, D.N. Standardizing biomarker testing for Canadian patients with advanced lung cancer. Curr. Oncol. 2018, 25, 73-82. [CrossRef]

71. Mehrad, M.; Roy, S.; Bittar, H.T.; Dacic, S. Next-Generation Sequencing Approach to Non-Small Cell Lung Carcinoma Yields More Actionable Alterations. Arch. Pathol. Lab. Med. 2018, 142, 353-357. [CrossRef] [PubMed]

72. Ikeda, S.; Schwaederle, M.; Mohindra, M.; Fontes Jardim, D.L.; Kurzrock, R. MET alterations detected in blood-derived circulating tumor DNA correlate with bone metastases and poor prognosis. J. Hematol. Oncol. 2018, 11, 76. [CrossRef] [PubMed]

73. Le, X.; Kowalski, D.; Cho, B.C.; Conte, P.; Felip, E.; Garassino, M.C.; Viteri, S.; Chang, G.C.; Richart, J.; Paz-Ares, L.; et al. Liquid biopsy to detect MET exon 14 skipping (METx14) and MET amplification in patients with advanced NSCLC: Biomarker analysis from VISION study. Cancer Res. 2020, 80, 3385. [CrossRef]

74. Diaz, L.A., Jr.; Bardelli, A. Liquid biopsies: Genotyping circulating tumor DNA. J. Clin. Oncol. 2014, 32, 579-586. [CrossRef]

75. Diehl, F.; Schmidt, K.; Choti, M.A.; Romans, K.; Goodman, S.; Li, M.; Thornton, K.; Agrawal, N.; Sokoll, L.; Szabo, S.A.; et al. Circulating mutant DNA to assess tumor dynamics. Nat. Med. 2008, 14, 985-990. [CrossRef] [PubMed]

76. Kidess, E.; Jeffrey, S.S. Circulating tumor cells versus tumor-derived cell-free DNA: Rivals or partners in cancer care in the era of single-cell analysis? Genome Med. 2013, 5, 70. [CrossRef]

77. Cheema, P.K.; Gomes, M.; Banerji, S.; Joubert, P.; Leighl, N.B.; Melosky, B.; Sheffield, B.S.; Stockley, T.; Ionescu, D.N. Consensus recommendations for optimizing biomarker testing to identify and treat advanced EGFR-mutated non-small-cell lung cancer. Curr. Oncol. 2020, 27, 321-329. [CrossRef]

78. Guo, R.; Luo, J.; Chang, J.; Rekhtman, N.; Arcila, M.; Drilon, A. MET-dependent solid tumours—Molecular diagnosis and targeted therapy. Nat. Rev. Clin. Oncol. 2020, 17, 569-587. [CrossRef]

79. Kim, E.K.; Kim, K.A.; Lee, C.Y.; Kim, S.; Chang, S.; Cho, B.C.; Shim, H.S. Molecular Diagnostic Assays and Clinicopathologic Implications of MET Exon 14 Skipping Mutation in Non-small-cell Lung Cancer. Clin. Lung Cancer 2019, 20, e123-e132. [CrossRef]

80. Davies, K.D.; Lomboy, A.; Lawrence, C.A.; Yourshaw, M.; Bocsi, G.T.; Camidge, D.R.; Aisner, D.L. DNA-Based versus RNA-Based Detection of MET Exon 14 Skipping Events in Lung Cancer. J. Thorac. Oncol. 2019, 14, 737-741. [CrossRef]

81. Poirot, B.; Doucet, L.; Benhenda, S.; Champ, J.; Meignin, V.; Lehmann-Che, J. MET Exon 14 Alterations and New Resistance Mutations to Tyrosine Kinase Inhibitors: Risk of Inadequate Detection with Current Amplicon-Based NGS Panels. J. Thorac. Oncol. 2017, 12, 1582-1587. [CrossRef] [PubMed]

82. Pruis, M.A.; Geurts-Giele, W.R.R.; Meijssen, I.C.; Dinjens, W.N.M.; Aerts, J.G.J.V.; Dingemans, A.M.C.; Lolkema, M.P.; Paats, M.S.; Dubbink, H.J. Highly accurate DNA-based detection and treatment results of MET exon 14 skipping mutations in lung cancer. Lung Cancer 2020, 140, 46-54. [CrossRef] [PubMed]

83. Benayed, R.; Offin, M.; Mullaney, K.; Sukhadia, P.; Rios, K.; Desmeules, P.; Ptashkin, R.; Won, H.; Chang, J.; Halpenny, D.; et al. High Yield of RNA Sequencing for Targetable Kinase Fusions in Lung Adenocarcinomas with No Mitogenic Driver Alteration Detected by DNA Sequencing and Low Tumor Mutation Burden. Clin. Cancer Res. 2019, 25, 4712-4722. [CrossRef] [PubMed]

84. Noonan, S.A.; Berry, L.; Lu, X.; Gao, D.; Barón, A.E.; Chesnut, P.; Sheren, J.; Aisner, D.L.; Merrick, D.; Doebele, R.C.; et al. Identifying the Appropriate FISH Criteria for Defining MET Copy Number-Driven Lung Adenocarcinoma through Oncogene Overlap Analysis. J. Thorac. Oncol. 2016, 11, 1293-1304. [CrossRef] 
85. Drilon, A.; Clark, J.W.; Weiss, J.; Ou, S.I.; Camidge, D.R.; Solomon, B.J.; Otterson, G.A.; Villaruz, L.C.; Riely, G.J.; Heist, R.S.; et al. Antitumor activity of crizotinib in lung cancers harboring a MET exon 14 alteration. Nat. Med. 2020, 26, 47-51. [CrossRef]

86. Le, X.; Paz-Ares, L.G.; Van Meerbeeck, J.; Viteri, S.; Cabrera Galvez, C.; Baz, D.V.; Kim, Y.C.; Kang, J.H.; Schumacher, K.M.; Karachaliou, N.; et al. Tepotinib in patients (pts) with advanced non-small cell lung cancer (NSCLC) with MET amplification (METamp). J. Clin. Oncol. 2021, 39, 9021. [CrossRef]

87. Reck, M.; Rodríguez-Abreu, D.; Robinson, A.G.; Hui, R.; Csőszi, T.; Fülöp, A.; Gottfried, M.; Peled, N.; Tafreshi, A.; Cuffe, S.; et al. Pembrolizumab versus Chemotherapy for PD-L1-Positive Non-Small-Cell Lung Cancer. N. Engl. J. Med. 2016, 375, 1823-1833. [CrossRef]

88. Gandhi, L.; Rodríguez-Abreu, D.; Gadgeel, S.; Esteban, E.; Felip, E.; De Angelis, F.; Domine, M.; Clingan, P.; Hochmair, M.J.; Powell, S.F.; et al. Pembrolizumab plus Chemotherapy in Metastatic Non-Small-Cell Lung Cancer. N. Engl. J. Med. 2018, 378, 2078-2092. [CrossRef]

89. Paz-Ares, L.; Luft, A.; Vicente, D.; Tafreshi, A.; Gümüş, M.; Mazières, J.; Hermes, B.; Çay Şenler, F.; Csőszi, T.; Fülöp, A.; et al. Pembrolizumab plus Chemotherapy for Squamous Non-Small-Cell Lung Cancer. N. Engl. J. Med. 2018, 379, 2040-2051. [CrossRef]

90. Hellmann, M.D.; Paz-Ares, L.; Bernabe Caro, R.; Zurawski, B.; Kim, S.W.; Carcereny Costa, E.; Park, K.; Alexandru, A.; Lupinacci, L.; de la Mora Jimenez, E.; et al. Nivolumab plus Ipilimumab in Advanced Non-Small-Cell Lung Cancer. N. Engl. J. Med. 2019, 381, 2020-2031. [CrossRef]

91. Paz-Ares, L.; Ciuleanu, T.E.; Cobo, M.; Schenker, M.; Zurawski, B.; Menezes, J.; Richardet, E.; Bennouna, J.; Felip, E.; Juan-Vidal, O.; et al. First-line nivolumab plus ipilimumab combined with two cycles of chemotherapy in patients with non-small-cell lung cancer (CheckMate 9LA): An international, randomised, open-label, phase 3 trial. Lancet Oncol. 2021, 22, 198-211. [CrossRef]

92. Hanna, N.H.; Schneider, B.J.; Temin, S.; Baker, S., Jr.; Brahmer, J.; Ellis, P.M.; Gaspar, L.E.; Haddad, R.Y.; Hesketh, P.J.; Jain, D.; et al. Therapy for Stage IV Non-Small-Cell Lung Cancer Without Driver Alterations: ASCO and OH (CCO) Joint Guideline Update. J. Clin. Oncol. 2020, 38, 1608-1632. [CrossRef]

93. Kato, Y.; Yamamoto, G.; Watanabe, Y.; Yamane, Y.; Mizutani, H.; Kurimoto, F.; Seike, M.; Gemma, A.; Akagi, K.; Sakai, H. Long-term efficacy of immune checkpoint inhibitors in non-small cell lung cancer patients harboring MET exon 14 skipping mutations. J. Clin. Oncol. 2021, 26, 1065-1072. [CrossRef]

94. Mayenga, M.; Assié, J.B.; Monnet, I.; Massiani, M.A.; Tabeze, L.; Friard, S.; Fraboulet, S.; Métivier, A.C.; Chouaïd, C.; Zemoura, L.; et al. Durable responses to immunotherapy of non-small cell lung cancers harboring MET exon-14-skipping mutation: A series of 6 cases. Lung Cancer 2020, 150, 21-25. [CrossRef]

95. Lau, S.C.; Perdrizet, K.; Giffoni de Mello Morais Mata, D.; Fung, A.S.; Liu, G.; Bradbury, P.A.; Shepherd, F.A.; Sacher, A.G.; Sheffield, B.; Hwang, D.; et al. Sequencing of systemic therapies in advanced NSCLC with MET exon 14 skipping mutation: A multicenter experience. J. Clin. Oncol. 2021, 39 (Suppl. S15), e21123. [CrossRef]

96. Awad, M.M.; Lee, J.K.; Madison, R.; Classon, A.; Kmak, J.; Frampton, G.M.; Alexander, B.M.; Venstrom, J.; Betzig Schrock, A. Characterization of 1387 NSCLCs with MET exon 14 (METex14) skipping alterations (SA) and potential acquired resistance (AR) mechanism. J. Clin. Oncol. 2020, 38, 9511. [CrossRef]

97. Xu, Z.; Li, H.; Dong, Y.; Cheng, P.; Luo, F.; Fu, S.; Gao, M.; Kong, L.; Che, N. Incidence and PD-L1 Expression of MET 14 Skipping in Chinese Population: A Non-Selective NSCLC Cohort Study Using RNA-Based Sequencing. Onco. Targets Ther. 2020, 13, 6245-6253. [CrossRef] [PubMed]

98. Lisberg, A.; Cummings, A.; Goldman, J.W.; Bornazyan, K.; Reese, N.; Wang, T.; Coluzzi, P.; Ledezma, B.; Mendenhall, M.; Hunt, J.; et al. A Phase II Study of Pembrolizumab in EGFR-Mutant, PD-L1+, Tyrosine Kinase Inhibitor Naïve Patients with Advanced NSCLC. J. Thorac. Oncol. 2018, 13, 1138-1145. [CrossRef] [PubMed]

99. Chen, P.; Yu, M.; Zhang, J.L.; Chen, W.Y.; Zhu, L.; Song, Y.; Jiang, C.Y.; Zhang, S. Significant benefits of pembrolizumab in treating refractory advanced pulmonary sarcomatoid carcinoma: A case report. World J. Clin. Cases 2020, 8, 2876-2884. [CrossRef] [PubMed]

100. Domblides, C.; Leroy, K.; Monnet, I.; Mazières, J.; Barlesi, F.; Gounant, V.; Baldacci, S.; Mennecier, B.; Toffart, A.C.; AudigierValette, C.; et al. Efficacy of Immune Checkpoint Inhibitors in Lung Sarcomatoid Carcinoma. J. Thorac. Oncol. 2020, 15, 860-866. [CrossRef]

101. Mo, J.; Hu, X.; Gu, L.; Chen, B.; Khadaroo, P.A.; Shen, Z.; Dong, L.; Lv, Y.; Chitumba, M.N.; Liu, J. Smokers or non-smokers: Who benefits more from immune checkpoint inhibitors in treatment of malignancies? An up-to-date meta-analysis. World J. Surg. Oncol. 2020, 18, 15. [CrossRef]

102. Backes, A.; Zech, B.; Felber, B.; Klebl, B.; Müller, G. Small-molecule inhibitors binding to protein kinases. Part I: Exceptions from the traditional pharmacophore approach of type I inhibition. Expert Opin. Drug Discov. 2008, 3, 1409-1425. [CrossRef] [PubMed]

103. Reungwetwattana, T.; Liang, Y.; Zhu, V.; Ou, S.I. The race to target MET exon 14 skipping alterations in non-small cell lung cancer: The Why, the How, the Who, the Unknown, and the Inevitable. Lung Cancer 2017, 103, 27-37. [CrossRef] [PubMed]

104. Landi, L.; Chiari, R.; Tiseo, M.; D'Incà, F.; Dazzi, C.; Chella, A.; Delmonte, A.; Bonanno, L.; Giannarelli, D.; Cortinovis, D.L.; et al. Crizotinib in MET-Deregulated or ROS1-Rearranged Pretreated Non-Small Cell Lung Cancer (METROS): A Phase II, Prospective, Multicenter, Two-Arms Trial. Clin. Cancer Res. 2019, 25, 7312-7319. [CrossRef] [PubMed]

105. Wolf, J.; Garon, E.B.; Groen, H.J.M.; Tan, D.S.W.; Robeva, A.; Le Mouhaer, S.; Carbini, M.; Chassot-Agostinho, A.; Heist, R.S. Capmatinib in MET exon 14-mutated, advanced NSCLC: Updated results from the GEOMETRY mono-1 study. J. Clin. Oncol. 2021, 39 (Suppl. S15), 9020. [CrossRef] 
106. Lu, S.; Fang, J.; Li, X.; Cao, L.; Zhou, J.; Guo, Q.; Liang, Z.; Cheng, Y.; Jiang, L.; Yang, N.; et al. Once-daily savolitinib in Chinese patients with pulmonary sarcomatoid carcinomas and other non-small-cell lung cancers harbouring MET exon 14 skipping alterations: A multicentre, single-arm, open-label, phase 2 study. Lancet Respir. Med. 2021, Online ahead of print. [CrossRef]

107. Business Wire. Available online: https://www.businesswire.com/news/home/20210715006100/en/Foundation-MedicineExpands-Indication-for-FoundationOne \%C2\%AELiquid-CDx-to-be-Used-as-a-Companion-Diagnostic-for-TABRECTA\%C2 $\%$ AE-capmatinib (accessed on 27 October 2021).

108. PR Newswire. Available online: https://www.prnewswire.com/news-releases/archerdx-receives-approval-for-archermetcompanion-diagnostic-for-tepmetko-tepotinib-in-advanced-non-small-cell-lung-cancer-in-japan-301029535.html (accessed on 27 October 2021).

109. Ali, A.; Goffin, J.R.; Arnold, A.; Ellis, P.M. Survival of patients with non-small-cell lung cancer after a diagnosis of brain metastases. Curr. Oncol. 2013, 20, e300-e306. [CrossRef] [PubMed]

110. Awad, M.M.; Leonardi, G.C.; Kravets, S.; Dahlberg, S.E.; Drilon, A.; Noonan, S.A.; Camidge, D.R.; Ou, S.I.; Costa, D.B.; Gadgeel, S.M.; et al. Impact of MET inhibitors on survival among patients with non-small cell lung cancer harboring MET exon 14 mutations: A retrospective analysis. Lung Cancer 2019, 133, 96-102. [CrossRef]

111. Goldberg, S.B.; Schalper, K.A.; Gettinger, S.N.; Mahajan, A.; Herbst, R.S.; Chiang, A.C.; Lilenbaum, R.; Wilson, F.H.; Omay, S.B.; $\mathrm{Yu}$, J.B.; et al. Pembrolizumab for management of patients with NSCLC and brain metastases: Long-term results and biomarker analysis from a non-randomised, open-label, phase 2 trial. Lancet Oncol. 2020, 21, 655-663. [CrossRef]

112. Costa, D.B.; Kobayashi, S.; Pandya, S.S.; Yeo, W.L.; Shen, Z.; Tan, W.; Wilner, K.D. CSF concentration of the anaplastic lymphoma kinase inhibitor crizotinib. J. Clin. Oncol. 2011, 29, e443-e445. [CrossRef]

113. Patel, J.D.; Le, X.; Veillon, R.; Anderson, I.C.; Bestvina, C.M.; Demedts, I.; Garassino, M.C.; Mazieres, J.; Morise, M.; Smit, E.F.; et al. Intracranial activity of tepotinib in patients (pts) with MET exon 14 (METex14) skipping NSCLC enrolled in VISION. J. Clin. Oncol. 2021, 39, 9084. [CrossRef]

114. Roth, K.G.; Mambetsariev, I.; Salgia, R. Prolonged survival and response to tepotinib in a non-small-cell lung cancer patient with brain metastases harboring MET exon 14 mutation: A research report. Cold Spring Harb. Mol. Case Stud. 2020, 6, a005785. [CrossRef] [PubMed]

115. Takamori, S.; Matsubara, T.; Fujishita, T.; Ito, K.; Toyozawa, R.; Seto, T.; Yamaguchi, M.; Okamoto, T. Dramatic intracranial response to tepotinib in a patient with lung adenocarcinoma harboring MET exon 14 skipping mutation. Thorac. Cancer 2021, 12, 978-980. [CrossRef]

116. Blanc-Durand, F.; Alameddine, R.; Iafrate, A.J.; Tran-Thanh, D.; Lo, Y.C.; Blais, N.; Routy, B.; Tehfé, M.; Leduc, C.; Romeo, P.; et al. Tepotinib Efficacy in a Patient with Non-Small Cell Lung Cancer with Brain Metastasis Harboring an HLA-DRB1-MET Gene Fusion. Oncologist 2020, 25, 916-920. [CrossRef] [PubMed]

117. Camidge, D.R.; Otterson, G.A.; Clark, J.W.; Ou, S.I.; Weiss, J.; Ades, S.; Conte, U.; Tang, Y.; Wang, S.C.E.; Murphy, D.; et al. Crizotinib in patients (pts) with MET-amplified non-small cell lung cancer (NSCLC): Updated safety and efficacy findings from a phase 1 trial. J. Clin. Oncol. 2018, 36, 9062. [CrossRef]

118. Camidge, D.R.; Otterson, G.A.; Clark, J.W.; Ou, S.I.; Weiss, J.; Ades, S.; Shapiro, G.I.; Socinski, M.A.; Murphy, D.A.; Conte, U.; et al. Crizotinib in Patients With MET-Amplified NSCLC. J. Thorac. Oncol. 2021, 16, 1017-1029. [CrossRef]

119. Reck, M.; Rodríguez-Abreu, D.; Robinson, A.G.; Hui, R.; Csőszi, T.; Fülöp, A.; Gottfried, M.; Peled, N.; Tafreshi, A.; Cuffe, S.; et al. Updated Analysis of KEYNOTE-024: Pembrolizumab Versus Platinum-Based Chemotherapy for Advanced Non-Small-Cell Lung Cancer With PD-L1 Tumor Proportion Score of 50\% or Greater. J. Clin. Oncol. 2019, 37, 537-546. [CrossRef]

120. Gadgeel, S.; Rodríguez-Abreu, D.; Speranza, G.; Esteban, E.; Felip, E.; Dómine, M.; Hui, R.; Hochmair, M.J.; Clingan, P.; Powell, S.F.; et al. Updated Analysis From KEYNOTE-189: Pembrolizumab or Placebo Plus Pemetrexed and Platinum for Previously Untreated Metastatic Nonsquamous Non-Small-Cell Lung Cancer. J. Clin. Oncol. 2020, 38, 1505-1517. [CrossRef]

121. Paz-Ares, L.; Vicente, D.; Tafreshi, A.; Robinson, A.; Soto Parra, H.; Mazières, J.; Hermes, B.; Cicin, I.; Medgyasszay, B.; RodríguezCid, J.; et al. A Randomized, Placebo-Controlled Trial of Pembrolizumab Plus Chemotherapy in Patients with Metastatic Squamous NSCLC: Protocol-Specified Final Analysis of KEYNOTE-407. J. Thorac. Oncol. 2020, 15, 1657-1669. [CrossRef]

122. Paz-Ares, L.G.; Ciuleanu, T.E.; Lee, J.S.; Urban, L.; Caro, R.B.; Park, K.; Sakai, H.; Ohe, Y.; Nishio, M.; Pluzanski, A.; et al. Nivolumab (NIVO) plus ipilimumab (IPI) versus chemotherapy (chemo) as first-line (1L) treatment for advanced non-small cell lung cancer (NSCLC): 4-year update from CheckMate 227. J. Clin. Oncol. 2021, 39l, 9016. [CrossRef]

123. Papadimitrakopoulou, V.A.; Wu, Y.L.; Han, J.Y.; Ahn, M.J.; Ramalingam, S.S.; John, T.; Okamoto, I.; Yang, J.C.H.; Bulusu, K.C.; Laus, G.; et al. Analysis of resistance mechanisms to osimertinib in patients with EGFR T790M advanced NSCLC from the AURA3 study. Ann. Oncol. 2018, 29, VIII741. [CrossRef]

124. Wu, Y.L.; Zhang, L.; Kim, D.W.; Liu, X.; Lee, D.H.; Yang, J.C.; Ahn, M.J.; Vansteenkiste, J.F.; Su, W.C.; Felip, E.; et al. Phase Ib/II Study of Capmatinib (INC280) Plus Gefitinib After Failure of Epidermal Growth Factor Receptor (EGFR) Inhibitor Therapy in Patients With EGFR-Mutated, MET Factor-Dysregulated Non-Small-Cell Lung Cancer. J. Clin. Oncol. 2018, 36, 3101-3109. [CrossRef] [PubMed]

125. Wu, Y.L.; Cheng, Y.; Zhou, J.; Lu, S.; Zhang, Y.; Zhao, J.; Kim, D.W.; Soo, R.A.; Kim, S.W.; Pan, H.; et al. Tepotinib plus gefitinib in patients with EGFR-mutant non-small-cell lung cancer with MET overexpression or MET amplification and acquired resistance to previous EGFR inhibitor (INSIGHT study): An open-label, phase 1b/2, multicentre, randomised trial. Lancet Respir. Med. 2020, 8, 1132-1143. [CrossRef] 
126. Sequist, L.V.; Han, J.Y.; Ahn, M.J.; Cho, B.C.; Yu, H.; Kim, S.W.; Yang, J.C.; Lee, J.S.; Su, W.C.; Kowalski, D.; et al. Osimertinib plus savolitinib in patients with EGFR mutation-positive, MET-amplified, non-small-cell lung cancer after progression on EGFR tyrosine kinase inhibitors: Interim results from a multicentre, open-label, phase 1b study. Lancet Oncol. 2020, 21, 373-386. [CrossRef]

127. Bauml, J.; Cho, B.C.; Park, K.; Lee, K.H.; Cho, E.K.; Kim, D.W.; Kim, S.W.; Haura, E.B.; Sabari, J.K.; Sanborn, R.E.; et al. Amivantamab in combination with lazertinib for the treatment of osimertinib-relapsed, chemotherapy-naïve EGFR mutant (EGFRm) non-small cell lung cancer (NSCLC) and potential biomarkers for response. J. Clin. Oncol. 2021, 39, 9006. [CrossRef]

128. Bahcall, M.; Sim, T.; Paweletz, C.P.; Patel, J.D.; Alden, R.S.; Kuang, Y.; Sacher, A.G.; Kim, N.D.; Lydon, C.A.; Awad, M.M.; et al. Acquired METD1228V Mutation and Resistance to MET Inhibition in Lung Cancer. Cancer Discov. 2016, 6, 1334-1341. [CrossRef]

129. Heist, R.S.; Sequist, L.V.; Borger, D.; Gainor, J.F.; Arellano, R.S.; Le, L.P.; Dias-Santagata, D.; Clark, J.W.; Engelman, J.A.; Shaw, A.T.; et al. Acquired Resistance to Crizotinib in NSCLC with MET Exon 14 Skipping. J. Thorac. Oncol. Off. Publ. Int. Assoc. Study Lung Cancer 2016, 11, 1242-1245. [CrossRef]

130. Fujino, T.; Kobayashi, Y.; Suda, K.; Koga, T.; Nishino, M.; Ohara, S.; Chiba, M.; Shimoji, M.; Tomizawa, K.; Takemoto, T.; et al. Sensitivity and Resistance of MET Exon 14 Mutations in Lung Cancer to Eight MET Tyrosine Kinase Inhibitors In Vitro. J. Thorac. Oncol. 2019, 14, 1753-1765. [CrossRef]

131. Recondo, G.; Bahcall, M.; Spurr, L.F.; Che, J.; Ricciuti, B.; Leonardi, G.C.; Lo, Y.C.; Li, Y.Y.; Lamberti, G.; Nguyen, T.; et al. Molecular Mechanisms of Acquired Resistance to MET Tyrosine Kinase Inhibitors in Patients with MET Exon 14-Mutant NSCLC. Clin. Cancer Res. 2020, 26, 2615-2625. [CrossRef]

132. Dagogo-Jack, I.; Moonsamy, P.; Gainor, J.F.; Lennerz, J.K.; Piotrowska, Z.; Lin, J.J.; Lennes, I.T.; Sequist, L.V.; Shaw, A.T.; Goodwin, K.; et al. A Phase 2 Study of Capmatinib in Patients With MET-Altered Lung Cancer Previously Treated With a MET Inhibitor. J. Thorac. Oncol. 2021, 16, 850-859. [CrossRef]

133. Engstrom, L.D.; Aranda, R.; Lee, M.; Tovar, E.A.; Essenburg, C.J.; Madaj, Z.; Chiang, H.; Briere, D.; Hallin, J.; Lopez-Casas, P.P.; et al. Glesatinib Exhibits Antitumor Activity in Lung Cancer Models and Patients Harboring MET Exon 14 Mutations and Overcomes Mutation-mediated Resistance to Type I MET Inhibitors in Nonclinical Models. Clin. Cancer Res. 2017, 23, 6661-6672. [CrossRef] [PubMed]

134. Grandal, M.M.; Havrylov, S.; Poulsen, T.T.; Koefoed, K.; Dahlman, A.; Galler, G.R.; Conrotto, P.; Collins, S.; Eriksen, K.W.; Kaufman, D.; et al. Simultaneous Targeting of Two Distinct Epitopes on MET Effectively Inhibits MET- and HGF-Driven Tumor Growth by Multiple Mechanisms. Mol. Cancer Ther. 2017, 16, 2780-2791. [CrossRef]

135. Strickler, J.H.; Weekes, C.D.; Nemunaitis, J.; Ramanathan, R.K.; Heist, R.S.; Morgensztern, D.; Angevin, E.; Bauer, T.M.; Yue, H.; Motwani, M.; et al. First-in-Human Phase I, Dose-Escalation and -Expansion Study of Telisotuzumab Vedotin, an Antibody-Drug Conjugate Targeting c-Met, in Patients with Advanced Solid Tumors. J. Clin. Oncol. 2018, 36, 3298-3306. [CrossRef] [PubMed]

136. Zhai, D.; Rogers, E.; Deng, W.; Zhang, X.; Lee, D.; Ung, J.; Zhang, H.; Liu, J.; Lu, Y.; Huang, J.; et al. Abstract 1321: TPX-0022, a polypharmacology inhibitor of MET/CSF1R/SRC for treatment of cancers with abnormal HGF/MET signaling. Cancer Res. 2019, 79, 1321. [CrossRef]

137. Spira, A.; Krebs, M.; Cho, B.C.; Besse, B.; Goldman, J.; Janne, P.; Lee, C.K.; Ma, Z.; Mansfield, A.; Minchom, A.; et al. Amivantamab in Non-small Cell Lung Cancer (NSCLC) with MET Exon 14 Skipping (METex14) Mutation: Initial Results from CHRYSALIS. In Proceedings of the International Association for the Study of Lung Cancer's (IASLC) 2021 World Conference on Lung Cancer (WCLC), Worldwide Virtual Event, Online, 8-14 September 2021, Abstract OA15.03. 